\title{
American State Supreme Court Justices, 1900-1970
}

\author{
Robert A. Kagan, Bobby D. Infelise, and Robert R. Detlefsen
}

What are the paths that lead to the state supreme court bench? If we can identify these paths, can we then determine that they produce distinctive patterns in a court's decision making? Based on a study of 694 judges who sat on 16 selected American state supreme courts between 1900 and 1970, this article finds that the appellate judiciary was drawn from a variety of legal and political backgrounds rather than from any single career line. The judges came from both non-elite and elite law schools. About half had no substantial lower court judicial experience. Over one-third had been public prosecutors, another third had held other elective political office, and only a small minority had practiced in multilawyer big-city law firms. The article reports changes over time in these and other judicial characteristics (such as age, turnover, political party affiliations) and describes interstate differences. Few significant statistical relationships are found, however, between the background characteristics of judges and selected characteristics of state supreme court opinions.

\section{INTRODUCTION}

A generation of political scientists has labored to find links between judicial decisions and the personalities, ideologies, and political party identifications of individual judges. ${ }^{1}$ The results have been mixed. Few legal scholars

Robert A. Kagan is a professor of political science, University of California, Berkeley. B.A. 1959, Harvard College; LL.B. 1962, Columbia University; Ph.D. 1974, Yale University.

Bobby D. Infelise is an attorney with Cox, Castle \& Nicholson, Los Angeles. B.A. 1977, J.D. 1980, University of California, Berkeley.

Robert R. Detlefsen is a Ph.D. candidate in political science, University of California, Berkeley. B.A. 1977, University of Massachusetts, Amherst.

This research was supported in part by a grant from the National Science Foundation Program in Law and Social Science, Grant no. GS-384-13. Special thanks is due Susan Lockwood and Andrew Rowen in connection with data gathering.

1. See, e.g., Harold Dwight Lasswell, Power and Personality ch. 4 (New York: W. W. Norton, 1948); Glendon Schubert, ed., Judicial Behavior: A Reader in Theory and Research (Chicago: Rand McNally, 1964); Sheldon Goldman, Voting Behavior on the United States Courts of Appeals Revisited, 69 Am. Pol. Sci. Rev. 491 (1975); David W. Adamany, The Party Variable in Judges' Voting: Conceptual Notes and a Case Study, 63 Am. Pol. Sci. Rev. 57 (1969); Stuart S. Nagel, Comparing Elected and Appointed Judicial Systems (Beverly Hills, Cal.: Sage Publications, 1973); Joel B. Grossman, Social Backgrounds and Judicial Decision-making, 79 Harv. L. Rev. 1551 (1966); Dean Jaros \& Bradley C. Canon, Dissent on State Supreme Courts: The Differential Significance of the Characteristics of Judges, 15 Midwest J. Pol. Sci. 
today would deny that political attitudes of judges influence court decisions, especially in controversial and novel cases. But statistical relationships between judges' social backgrounds (including their political allegiances and career experiences) and outcomes in broad classes of cases, while sometimes suggestive, have rarely been very strong. ${ }^{2}$

One reason, of course, is that judges feel constrained to decide most cases in accordance with legal doctrine as conventionally interpreted in the profession. Even when there is more room for discretion, there are too many intervening variables-such as the precise form a general issue takes in a particular case, or the influence of counsel and judicial colleagues-to expect clean statistical relationships between a judge's background and that judge's decisions in broad classes of cases such as "civil liberties" or "criminal procedure." Finally, there is much variation among members within such groups as Republicans, former prosecuting attorneys, and elite law school graduates; membership in such a group is not likely by itself to strongly predict a judge's attitudes on the bench.

That said, knowledge of judges' social backgrounds, education, and career experiences might still be of considerable interest. Over time, it is plausible that we will end up with a different judicial culture-and hence with somewhat different judicial role conceptions, philosophies, and decisions-if appellate judges in a state court system are recruited from only one political party, or primarily from the ranks of former politicians with no prior judicial experience, or from the corporate bar. Put otherwise, judicial background might be viewed as operating cumulatively, affecting the character and style of courts (not merely individual judges) and helping to explain how and why one court differs in spirit from another.

But these are only hypotheses. In fact, very little is known about the education and career experiences of American judges as a group, about the judges of one state as compared with another, ${ }^{3}$ or about how those characteristics have been evolving and whether they have any noticeable effect on court decisions.

This article seeks to add to that limited body of knowledge. Section I sets

322 (1971); Richard Johnston, Supreme Court Voting Behavior: A Comparison of the Warren and Burger Courts, in Robert L. Peabody, ed., Cases in American Politics (New York: Praeger, 1976); James L. Gibson, From Simplicity to Complexity: The Development of Theory in the Study of Judicial Behavior, 5 Pol. Behav. 7 (1983).

2. But see Lawrence Baum, Judicial Specialization, Litigant Influence, and Substantive Policy: The Court of Customs and Patent Appeals, 11 Law \& Soc'y Rev. 823 (1977); Kenneth N. Vines, Federal District Judges and Race Relations Cases in the South, 26 J. Pol. 338 (1964); Frank J. Sorauf, The Wall of Separation: The Constitutional Politics of Church and State (Princeton, N.J.: Princeton University Press, 1976); C. Neal Tate, Personal Attribute Models of the Voting Behavior of U.S. Supreme Court Justices: Liberalism in Civil Liberties and Economic Decisions, 1946-1978, 75 Am. Pol. Sci. Rev. 355 (1981).

3. See, however, Bradley C. Canon, Characteristics and Career Patterns of State Supreme Court Justices, 45 St. Gov't 34 (1972); id., The Impact of Formal Selection Processes on the Characteristics of Judges-Reconsidered, 6 Law \& Soc'y Rev. 579 (1972); Henry Robert Glick, Supreme Courts in State Politics: An Investigation of the Judicial Role (New York: Basic Books, 1971); Kenneth N. Vines, The Judicial Role in the American States: An Exploration, in Joel B. Grossman \& Joseph Tanenhaus, eds., Frontiers of Judicial Research (New York: John Wiley \& Sons, 1969). 
forth our research method. Section II reports our findings concerning changes over the 1900-1970 period in the careers, education, and judicial experience of American state supreme court judges as a group; the findings are based on a study of 694 judges who sat on 16 representative state supreme courts in those years. Section III points out interstate differences. Section IV examines relationships between such differences in court composition and certain court outputs-reversal rates, dissent rates, opinion characteristics, and outcomes in some kinds of cases.

\section{RESEARCH METHOD}

This study stemmed from a larger research project that focuses on the business of American state supreme courts in the 1870-1970 period-their caseloads and decision structures, the kinds of parties they served and cases they decided, the frequency of reversal and dissent, and the length and citation patterns of their opinions. ${ }^{4}$ First, a representative sample of 16 states was drawn from the 48 states (excluding Alaska and Hawaii) that existed for most of the survey period. Next, it was decided to sample cases at 5-year intervals-21 sample years-from 1870 to 1970 . Finally, 18 cases were selected at random from the opinions published by each of those 16 courts in each of the 21 sample years, ${ }^{5}$ yielding a sample of 5,904 cases. For each case a team of law students coded the type of issue, nature of the parties, result, and various opinion characteristics.

We used the same 16 states for our study of state supreme court (ssc) judges. They included 5 urban and industrial states-Rhode Island, New Jersey, Michigan, Illinois, and California; 4 southern and border states-Alabama, Tennessee, North Carolina, West Virginia; 2 plains state-Kansas and South Dakota; 2 western states-Nevada and Idaho; and 3 "miscellaneous" states -Maine, Minnesota, and Oregon. For each state, we examined a variety of published judicial biographies. The most complete, in terms of covering judges, was Who's Who. ${ }^{6}$ Information prior to 1900 was sparse; hence we decided to concentrate on judges sitting from 1900 to $1970 .^{7}$

The major weakness in the data is that the biographical sketches in Who's Who are self-reported. The judges emphasized whatever they chose, and left out what they wanted. For many items, the information is probably reliable:

4. See Robert A. Kagan, Bliss Cartwright, Lawrence M. Friedman, \& Stanton Wheeler, The Business of State Supreme Courts, 1870-1970, 30 Stan. L. Rev. 121 (1977); id., The Evolution of State Supreme Courts, 76 Mich. L. Rev. 961 (1978); Lawrence M. Friedman et al., State Supreme Courts: A Century of Style and Citation, 33 Stan. L. Rev. 773 (1981); Note, Courting Reversal: The Supervisory Role of State Supreme Courts, 87 Yale L.J. 1191 (1978).

5. Thus unpublished opinions were excluded. We also excluded short per curiam or memorandum opinions-those less than one printed page. The total sample $(5,904)$ is smaller than the original target figure (18 cases $\times 21$ sample years $\times 16$ courts $=6,048$ cases) because two sample states, South Dakota and Idaho, were not admitted to the union until 1889 and 1890 and therefore provided no cases for the 1870-85 sample years.

6. The Dictionary of American Judges, published in 1955 , was useful, but covered only judges sitting in that year.

7. The term judges, when used in the rest of this article, will mean state supreme court judges unless stated otherwise. 
the judges were not likely to tell untruths about their birth dates or birthplaces, the law schools they attended, the public offices they held. But given the image of judicial neutrality the profession fosters, some judges may have underreported their memberships in political parties or even have left out some public offices. For almost a quarter of the judges, information on the type of private legal practice was sketchy or missing.

In addition, the Who's Who data gave us no reliable basis for determining social and economic backgrounds. In most cases, the judges did not report their fathers' occupations. We have used the consistently available information on college and legal education to draw some inferences in this regard, but as will appear, these inferences are necessarily speculative and tentative.

In all, 815 judges sat on the 16 sscs in the 1900-1970 period. Information was available for 694; the "missing judges" were not concentrated in any particular states. The information coded for each judge included birthplace, college and legal education, type and place of law practice, public offices held, judicial experience prior to accession to the ssc, age at accession to court and at retirement, postjudicial offices held, political party membership and offices, publications, and law teaching activities.

\section{Judicial BACKgRound AND TENURE: NATIONAL TRENDS}

In this section, the judges of the 16 courts in our study will be examined as a group, undifferentiated by state. Their professional and educational backgrounds can indicate patterns of judicial recruitment for SSCs in the country as a whole in the 1900-1970 period.

\section{A. Prior Judicial Experience}

In most industrialized countries, a position on a high appellate court represents the culmination of a lengthy judicial career. Aspirants to a place on the judiciary start at the bottom of the hierarchy of courts; they first must pass a rigorous civil service-type examination. Promotion to appellate courts is based on seniority and on demonstration of high standards of judicial craftsmanship in lower court adjudication. ${ }^{8}$

Nearly the opposite is true, it has often been observed, of recruitment to American judicial positions. Against the ideal of the highly "professional" judge-a scholarly and detached expert on the intricacies of the law-Americans have often called for judges who were more directly responsive to current demands for justice, or individuals who had distinguished themselves as

8. See Daniel J. Meador, German Appellate Judges: Career Patterns and American-English Comparisons, 67 Judicature 16 (June-July 1983); id., English Appellate Judges from an American Perspective, 66 Geo. L.J. 1349 (1978); John Philip Dawson, The Oracles of the Law (Ann Arbor: University of Michigan Law School, 1968); Mirjan Damaska, Structures of Authority and Comparative Criminal Procedure, 84 Yale L.J. 480, 509, 522 (1975); Henry W. Ehrmann, Comparative Legal Cultures 70-77 (Englewood Cliffs, N.J.: Prentice-Hall, 1976); Henry Abraham, The Judicial Process (3d ed. New York: Oxford University Press, 1975). 
political leaders or courtroom advocates. ${ }^{9}$ Thus judges in most American states are popularly elected. In others, they are appointed as a reward for political service or "after proving themselves to be people of good sense to politicians who control the judicial patronage." ${ }^{10}$ Lateral entry at even the highest level of the judiciary is not uncommon. Of the justices appointed to the United States Supreme Court since 1930, only one in four (24\%) had served extensive apprenticeships on lower courts, that is, of five years or more." Of the 17 justices who served on the Court during Earl Warren's tenure as chief justice (1953-69), 10 had never served as judges at all prior to appointment; ${ }^{12}$ of the 7 who had, Hugo Black had been an Alabama municipal police court judge for a year, and John Harlan had been on the U.S. court of appeals for one year. ${ }^{13}$

Proponents of this system could point out that men with little or no prior judicial experience have proved to be distinguished Supreme Court jùstices, beginning with Chief Justice John Marshall, and including (somewhat arbitrarily) Justices Story, Brandeis, Black, Frankfurter, Douglas, Warren, and both Harlans. Critics would argue that while a few with great intelligence and judgment can master the judicial craft quickly, others who have not proved themselves in the lower courts have added little to the High Court but mediocrity, ${ }^{14}$ ad hoc political judgments, and confusing opinions.

Recruitment of state supreme court judges reflects elements of both the "professional experience" approach and the "bringing in new blood" approach, free of the presumably conservatizing effects of a long lower court apprenticeship. Based on our sample of 16 states, almost half of American ssC judges in the 1900-1970 period were experienced, in the sense of having served on the lower courts for over five years before appointment or election to the court. The other half, however, were "quick ascenders"; they moved to the court in a direct leap from political office or private practice, or after a perfunctory year or two of lower court experience (see table 1).

Surprisingly, there has been little change in the amount of prior judicial experience among SSC judges during this century, little drift either toward or away from a more narrowly "professional" judiciary. Of the judges who sat in the 1900-1920 period, $42.6 \%$ had served substantial lower court terms-

9. See, e.g., Richard E. Ellis, The Jeffersonian Crisis: Courts and Politics in the Young Republic (New York: Oxford University Press, 1971); Lawrence M. Friedman, A History of American Law pt. 3, ch. 2 (New York: Simon \& Schuster, 1973).

10. Bruce A. Ackerman, Private Property and the Constitution 187 (New Haven, Conn.: Yale University Press, 1977).

11. See data presented in Abraham, supra note 8, at ch. 2.

12. These were Burton, Clark, Douglas, Fortas, Frankfurter, Goldberg, Jackson, Reed, White, and Warren himself.

13. Of the nine judges on the present Court, however, only Powell, Rehnquist, and White were wholly without judicial experience when appointed. See John Cound, The Justices of the Supreme Court, app. A in William B. Lockhart, Yale Kamisar, \& Jesse H. Choper, The American Constitution (5th ed. St. Paul, Minn.: West Publishing Co., 1981).

14. Cf. former Senator Roman Hruska, who asked, during the controversy over President Nixon's nomination of Harold Carswell, whether mediocre people are not entitled to some representation on the court. 
over five years of experience. A virtually identical proportion (44.9\%) of judges sitting in 1950-70 had done so. ${ }^{15}$

There has been some increase in the proportion of judges who had served for a very long time on lower courts. About $11 \%$ of the 1900-1920 judges had over 15 years of prior judicial experience; this increased to almost $19 \%$ of the 1950-70 judges. Consequently, the mean length of prior judicial experience went up slightly-from 5.9 years earlier in the century to 6.6 years more recently. ${ }^{16}$

Only $6 \%$ of the judges who sat in the $1900-1920$ period had prior appellate court experience. A substantially higher proportion-about $18 \%$-of the 1950-70 judges had served on lower appellate courts. This increase reflects the fact that in the 1900-1920 period only 5 of our 16 states (Alabama, California, Illinois, New Jersey, and Tennessee) had intermediate appellate courts (IACs). In the 1960s, however, 3 additional states in our sample (Michigan, North Carolina, and Oregon) created IACs, and the 5 states that already

TABLE 1

Lower Court Experience Before Accession to State Supreme Court, 1900-1970

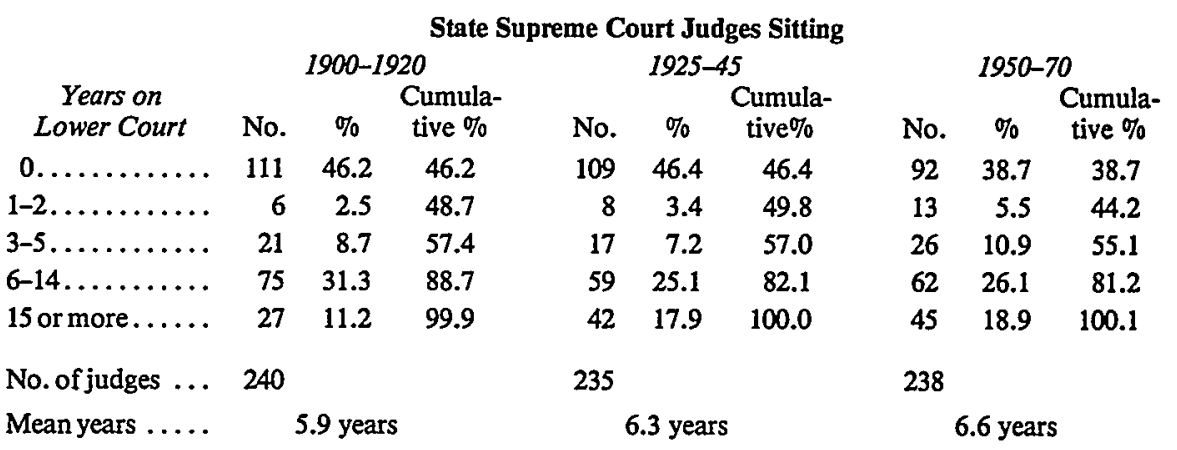

NotE: Discrepancies in number of judges from table to table are the result of missing data. Readers should also note that some judges were sitting in more than one time period.

15. In contrast, appointments to the U.S. Supreme Court have shown a decline in prior judicial experience. Over half $(56 \%)$ of the justices appointed between 1870 and 1900 had over five years of prior judicial experience, but only $41 \%$ of the justices appointed between 1900 and 1930 did, and as noted above, only one in four (24\%) of the justices appointed since 1930 have had extensive judicial apprenticeships. See Abraham, supra note 8 .

16. There has been some decrease in the number of judges who skipped the lower courts entirely, from $46.2 \%$ in 1900-1920 to $38.7 \%$ in 1950-70, but that minor "trend" is even less sharp when we correct for the disproportionate impact of New Jersey judges on the 1900-1920 figure (New Jersey judges had less prior judicial experience on the average then other states' judges in the 1900-1945 period, and there were many more of them; New Jersey's Court of Errors and Appeals then had 16 members). When we take the average of all judges in each state and then average the results from the 16 states, New Jersey's impact is moderated: the average proportion of judges with no prior judicial experience is then $43.4 \%$ (1900-1920), $43.9 \%(1925-45)$, and $39.4 \%$ (1950-70).

Moreover, there has been a slight increase in the number of judges who served only a brief lower court term of one or two years. The percentage of judges with two years or less prior judicial experience (including no years) was $48.7 \%(1900-1920), 49.8 \%(1925-45)$, and $44.2 \%$ (1950-70). Correcting for New Jersey, the comparable figures are $46 \%, 47.8 \%$, and $45 \%$. 
had IACs expanded them in the course of the 1950-70 period. ${ }^{17}$ These changes, of course, expanded the pool of experienced appellate court judges from which candidates for the ssc might be drawn. As more states add IACs, one might expect the proportion of judges with appellate judging experience to grow somewhat further. Nevertheless, for the ssc judiciary as a whole, prior appellate court service was quite infrequent in the 1900-1970 years.

\section{B. Pre-judicial Career}

Whether or not an SSC judge had lower court judicial experience, $\mathrm{h}^{18}$ was likely to have held some other public office earlier in his career. The most common pre-judicial public office has been public prosecutor. In most states, district attorneys and attorneys general are elected to office. In the others, appointment to these positions, and often even appointment as their assistants, is a political process. Prosecuting attorneys, therefore, are necessarily in close contact both with political party officials and with the judges before whom they regularly appear. Over one-third (37.1\%) of ssc judges sitting in the 1900-1920 period had held public law enforcement positions, a proportion that undoubtedly far exceeded the ratio of prosecuting attorneys to lawyers in general. Moreover, as table 2 shows, the percentage of judges with law enforcement backgrounds increased to $43.7 \%$ for judges sitting in $1925-45$, and to $42.9 \%$ for $1950-70 .^{19}$

TABLE 2

State Supreme Court Judges' Pre-Judicial Careers: Prosecutorial and Political Office, $1900-1970$

\begin{tabular}{|c|c|c|c|c|c|c|}
\hline \multirow{3}{*}{ Prior Career } & \multicolumn{6}{|c|}{ State Supreme Court Judges Sitting } \\
\hline & \multicolumn{2}{|c|}{$1900-1920$} & \multicolumn{2}{|c|}{$1925-45$} & \multicolumn{2}{|c|}{$1950-70$} \\
\hline & No. & $\%$ & No. & $\%$ & No. & $\%$ \\
\hline Public prosecutor . . . . . . . . . & 93 & 37.1 & 104 & 43.7 & 103 & 42.9 \\
\hline Other elective political office .. & 95 & 37.8 & 88 & 37.0 & 70 & 29.2 \\
\hline Neither $\ldots \ldots \ldots \ldots \ldots \ldots \ldots$ & 102 & 40.6 & 77 & 32.4 & 92 & 38.3 \\
\hline No. of judges ...... & 251 & & 238 & & 240 & \\
\hline
\end{tabular}

NorE: See note to table 1. Some judges had been both prosecutors and holders of other elective political office and are counted in both categories. Therefore, the total number of instances is larger than the number of judges, and the percentages do not total 100 .

17. This reflected a more general trend. Many states added IACs in the 1960 s and gave their courts discretion to select which cases to review. See Daryl R. Fair, State Intermediate Appellate Courts: An Introduction, 24 W. Pol. Q. 415 (1971); and Kagan, et al., The Evolution of State Supreme Courts, supra note 4. The eight states in our sample that had not created IACs by 1970 were Maine, Rhode Island, West Virginia, Minnesota, Kansas, Idaho, Nevada, and South Dakota.

18. In the entire 1900-1970 period, there was only one female SSC judge in our 16-state sample-Susie Sharp of North Carolina.

19. Of judges with law enforcement experience, $46.7 \%$ were in county prosecutor offices, $39.5 \%$ in state attorney general offices, and $12.5 \%$ in U.S. attorney offices. These figures include those who served as assistant district attorneys and assistant attorneys general. The clearest historical trend is an increase in the number of judges with experience as state attorneys general relative to local district attorneys.

Canon, Characteristics and Career Patterns, supra note 3, examined the backgrounds of SSC judges in all 50 states in the 1961-68 period. He states that as many as $51 \%$ of judges had held positions in prosecutors' and county attorneys' offices, acknowledging that it is often not clear from the job title whether a position was prosecutorial in nature (at 39 ). 
Earlier in their careers, about one-third of ssc judges held other elective political offices such as mayor, county supervisor, or state legislator, with the latter being by far the most common. ${ }^{20}$ An average of $37.4 \%$ of judges sitting during the 1900-1945 years had held such political offices; there was a decline to a still substantial $29.9 \%$ of those judges sitting from 1950 to $1970 .{ }^{21}$

Finally, another third-about $37 \%$-of these judges held no political office or prosecutorial position prior to their judicial careers, having been for the most part in private practice only. No clear trend is apparent with respect to experience in public office as a prerequisite of an SsC judgeship. The proportion who had held no political or prosecutorial office dropped from $40.6 \%$ in $1900-1920$ to $32.4 \%$ in $1925-45$ but increased to $36.3 \%$ in $1950-70$. These judges, however, were not necessarily innocent of political experience. Twelve percent acknowledged having held offices in political parties (such as county chairman or state treasurer) or having been delegates to presidential nominating conventions. ${ }^{22}$ Almost $20 \%$ had served as counsel to government agencies or been members of local school boards. ${ }^{23}$ And of course, there are many ways a private lawyer can be deeply involved in political activity without holding any public or party office. ${ }^{24}$

Over all, if we combine ssc judges who held public law enforcement office, other political or elective office, or a political party office, at least threequarters can be classified as clearly having come from a career closely involved with politics. But this proportion, too, has shown no pronounced rise or fall over the course of this century. ${ }^{25}$ Thus it is difficult to conclude from this prior career data that the ssc bench has become either more or less insulated from electoral or party politics.

\section{Judicial Experience and Pre-judicial Careers Combined}

A more complete picture of judge-recruitment patterns can be drawn by combining the information on judicial and nonjudicial careers. Table 3 shows the proportion of judges who served five or more years as lower court judges. Our assumption here is that once a person has spent at least five years on the

20. Of judges who held political office, $76.4 \%$ were state legislators, $16.8 \%$ were local executives (mayors, county executive officers), and $3 \%$ were United States congressmen. The changes in this distribution over time are not striking.

21. An average of $13 \%$ of the judges in all three time periods held both prosecutorial and other political office prior to their judicial careers, and we have included these judges in both categories. This is why the percentages in table 2 would exceed 100 if they were totaled.

22. It is quite possible that because of the ideal of the "neutral" judge, SSC judges tend to underreport affiliations with political party organizations in their statements for official biographies.

23. The percentage of judges who did not hold prosecutorial or other significant political office but who were political party officials has been relatively stable over time. But the percentage of those who served as counsel to public agencies or on school boards jumped from $15.6 \%$ of all judges in the 1900-1945 period to $26.1 \%$ of $1950-70$ judges.

24. See, e.g., John E. Crow, Subterranean Politics: A Judge Is Chosen, 12 J. Pub. L. 275 (1963).

25. The one marked change in any indicator of political involvement is a decrease-from $86 \%$ in $1900-1920$ to $70.5 \%$ in $1950-70$-in the proportion of judges whose self-reported biographical statements disclose some political party identification. 
bench, his prior occupation can meaningfully be characterized as "judge.",26 By that definition, we see again that close to half of the judges were "professional judges" before they reached the SSC and also that this proportion has been remarkably stable over time. The other half of the judges-the "quick ascenders" - were divided almost equally among those with courtroomoriented prosecutorial experience, backgrounds in other political office, and backgrounds in private legal practice only.

The one hint of a trend over time is a small decline in judges who jumped quickly to the top from political office. As table 4 discloses, in the 1900-1920 period, judges who had held political office reached the high court slightly more rapidly, on the average, than their brethren; $60.4 \%$ of judges with prior careers in politics reached the court without five or more years of prior judicial experience, compared to about $53 \%$ of those with prior careers in law enforcement or private practice only. By 1950-70, however, this tenuous advantage had narrowed; $54.4 \%$ of the former politicians were "quick ascenders" compared with $53.4 \%$ of former prosecutors and $48.9 \%$ of the former private practitioners.

\section{Legal Education}

At the turn of the century, most American lawyers had not been educated in law schools. They had been admitted to the bar after "reading law" as a clerk to a practicing attorney. But law schools were on the rise. The most prestigious were affiliated with leading private universities (such as Harvard and Columbia) and select state universities (such as Michigan). While they had some students from all walks of life, it is probable that most elite law

TABLE 3

State Supreme Court Judges' Prior Careers: Judicial and Public Office, 1900-1970

\begin{tabular}{|c|c|c|c|c|c|c|}
\hline \multirow[b]{2}{*}{ Prior Career } & \multicolumn{2}{|c|}{$1900-1920$} & \multicolumn{2}{|c|}{$1925-45$} & \multicolumn{2}{|c|}{$1950-70$} \\
\hline & No. & $\%$ & No. & $\%$ & No. & $\%$ \\
\hline Lower court judge 5 or more years ... & 109 & 45.4 & 107 & 45.4 & 116 & 48.7 \\
\hline $\begin{array}{l}\text { Lower court judge less than } 5 \text { years } \\
\text { and: }\end{array}$ & & & & & & \\
\hline Public prosecutor $\ldots \ldots \ldots \ldots$ & 47 & 19.6 & 57 & 24.3 & 55 & 23.1 \\
\hline Other elective political office & 55 & 22.9 & 49 & 20.9 & 37 & 15.5 \\
\hline Private practice $\ldots \ldots \ldots, \ldots, \ldots$ & 52 & 21.7 & 40 & 17.0 & 45 & 18.9 \\
\hline No. of judges . . & 240 & & 235 & & 238 & \\
\hline
\end{tabular}

NotE: See note to table 1 . Some judges had been both prosecutors and holders of other elective political office and are counted in both categories. Therefore, the total number of instances is larger than the number of judges, and the percentages do not total 100 .

\footnotetext{
26. It is inevitably arbitrary to choose any number of years of experience as dividing "experienced" from "less experienced" judges, or to say that a certain amount of judicial experience so outweighs prior career experiences that we can characterize a person's primary career background as "judge." But most people would agree, we think, that a demanding professional job like judging is not quickly mastered and that at least five years of experience àre required before the professional has developed fully his or her own perspective on the job. See Lenore Alpert, Learning About Trial Judging: The Socialization of State Trial Judges, in James A. Cramer, ed., Courts and Judges (New York: Sage Publications, 1981).
} 
school students were drawn from wealthier Protestant families. ${ }^{27}$ However, proprietary and night law schools, unaffiliated with universities, were growing very rapidly. They were less expensive than the university schools, and they served the upwardly mobile sons of the immigrant groups pouring into the rapidly growing cities. ${ }^{28}$

Except for those attending Harvard, most students at the leading university law schools in the 1890 s did not have college degrees. ${ }^{29}$ Only in the $1930 \mathrm{~s}$ did most states require prospective lawyers to attend law school in order to be admitted to the bar. And in the 1930s the Association of American Law Schools began an ultimately successful drive to withhold accreditation from law schools that admitted students without college degrees. ${ }^{30}$

Table 5 shows the percentage of judges in our 16-state sample who attended college, who graduated from law school, and who became lawyers via clerkships without having gone to law school. The judges sitting in 1900-1920 were for the most part educated in the nineteenth century. ${ }^{31}$ The fact that $71 \%$ had gone to college and $41 \%$ to law school suggests that they were drawn disproportionately from the wealthier classes. The same may be true for the 1925-45 judges as well: $73 \%$ had gone to college, even though the growth of proprietary and night law schools early in the century probably produced a decline in the proportion of lawyers with college degrees. (In New York, 35\% of the lawyers admitted to the bar in 1899 had college degrees; in 1910, the comparable figure was only $8 \%$.) 32 $^{32}$

Nevertheless, there was a steady increase in the proportion of judges who

TABLE 4

State Supreme Court Judges' Lower Court Experience by Pre-Judicial Careers, 1900-1970

\begin{tabular}{|c|c|c|c|c|c|c|c|c|c|}
\hline \multirow[b]{2}{*}{ Prior Career } & \multicolumn{3}{|c|}{$\begin{array}{c}\text { 1900-1920 } \\
5 \text { Years } \\
\text { Lower Court } \\
\text { Experience }\end{array}$} & \multicolumn{3}{|c|}{$\begin{array}{l}1925-45 \\
5 \text { Years } \\
\text { Lower Court } \\
\text { Experience }\end{array}$} & \multicolumn{3}{|c|}{$\begin{array}{l}\text { 1950-70 } \\
5 \text { Years } \\
\text { Lower Court } \\
\text { Experience }\end{array}$} \\
\hline & No. & $\%$ Yes & $\%$ No & No. & $\%$ Yes & $\%$ No & No. & $\%$ Yes & $\%$ No \\
\hline Public prosecutor........... & 89 & 47.2 & 52.8 & 103 & 44.7 & 55.3 & 103 & 46.6 & 53.4 \\
\hline Other elective political office.... & 91 & 39.6 & 60.4 & 86 & 43.0 & 57.0 & 68 & 45.6 & 54.4 \\
\hline Neither (private practice only)... & 97 & 46.4 & 53.6 & 76 & 47.4 & 52.6 & 92 & 51.1 & 48.9 \\
\hline No. of judges & 240 & & & 235 & & & 238 & & \\
\hline
\end{tabular}

Nore: See note to table 1. Some judges had been both prosecutors and holders of other elective political office and are counted in both categories. Therefore, the total number of instances is larger than the number of judges, and the percentages do not total 100 .

27. See Jerold S. Auerbach, Unequal Justice: Lawyers and Social Change in Modern America 28-29 (New York: Oxford University Press, 1976); Robert Stevens, Two Cheers for 1870: The American Law School, in Donald Fleming \& Bernard Bailyn, eds., Law in American History (Boston: Little, Brown \& Co., 1971).

28. See Auerbach, supra note 27, at 95-97. In 1905, Auerbach reports, one-third of all law students attended night law schools.

29. Id.

30. Stevens, supra note 27 , at $493-511$.

31. For judges sitting in 1900-1920, the average age on first reaching the court was 50 . An "average" judge elected or appointed in 1920 was 30 in 1900 .

32. Auerbach, supra note 27, at 95. 
had gone to law schools that apparently did not require college training as a prerequisite of admission-the less prestigious law schools. ${ }^{33}$ In the 1925-45 period, $71 \%$ of the judges had gone to law school, and in 1950-70, 93\% had. Yet the percentage who had gone to college increased only slightly-to $78 \%$ of the 1950-70 judges. ${ }^{34}$

The relative rise of judges educated in the less prestigious law schools is also reflected in table 6, which reflects our admittedly rough - and inevitably controversial-attempt to classify law schools according to prestige. The ten law schools we placed in the first rank were Harvard, Yale, Columbia, Michigan, and similar university law schools with national reputations for excellence. ${ }^{35}$ The second reputational rank includes university law schools gener-

TABLE 5

Education of State Supreme Court Judges, 1900-1970

\begin{tabular}{|c|c|c|c|c|c|c|}
\hline & \multicolumn{6}{|c|}{ State Supreme Court Judges Sitting } \\
\hline & 1900 & 1920 & & & & \\
\hline & No. & $\%$ & No. & $\%$ & No. & \\
\hline ................... & 178 & 70.9 & 174 & 73.1 & 188 & \\
\hline Law school. & 102 & 40.6 & 167 & 71.2 & 223 & \\
\hline Clerkship ............ & 149 & 59.4 & 71 & 29.8 & 17 & \\
\hline No. of judges & 251 & & 238 & & 240 & \\
\hline
\end{tabular}

Note: Some judges received more than one kind of training and are counted in more than one category in a time period. Therefore, the total number in each column exceeds the total number of judges sampled.

TABLE 6

Prestige of Law Schools Attended by State Supreme Court Judges, 1900-1970

\begin{tabular}{|c|c|c|c|c|c|c|c|c|c|}
\hline & \multicolumn{9}{|c|}{ State Supreme Court Judges Sitting } \\
\hline & & $900-1920$ & & & $925-45$ & & & $950-70$ & \\
\hline & No. & $\begin{array}{l}\% \text { of } \\
\text { Total }\end{array}$ & $\begin{array}{c}\% \text { Law } \\
\text { School } \\
\text { Graduates } \\
(N=102)\end{array}$ & No. & $\begin{array}{l}\% \text { of } \\
\text { Total }\end{array}$ & $\begin{array}{c}\text { \% Law } \\
\text { School } \\
\text { Graduates } \\
(N=167)\end{array}$ & No. & $\begin{array}{l}\% \% \text { of } \\
\text { Total }\end{array}$ & $\begin{array}{c}\text { \% Law } \\
\text { School } \\
\text { Graduate } \\
(N=223)\end{array}$ \\
\hline Rank $1 \ldots . .$. & 43 & 17.1 & 42.1 & 57 & 23.9 & 34.1 & 64 & 26.7 & 28.7 \\
\hline Rank 2 ....... & 23 & 9.2 & 22.5 & 38 & 16.0 & 22.8 & 59 & 24.6 & 26.5 \\
\hline Rank 3 ....... & 11 & 4.4 & 10.9 & 36 & 15.1 & 21.5 & 59 & 24.6 & 26.5 \\
\hline Rank 4 ....... & 25 & 10.0 & 24.5 & 36 & 15.1 & 21.5 & 41 & 17.1 & 18.4 \\
\hline Clerkship .... & 149 & 59.4 & - & 71 & 29.8 & - & 17 & 7.1 & - \\
\hline No. of judges . & 251 & & & 238 & & & 240 & & \\
\hline
\end{tabular}

33. In the early 1920s, the Association of American Law Schools (AALS) and the American Bar Association (ABA) standards called for at least two years of college as a prerequisite of law school. Yet in 1927, the ABA standards were met by only half the law schools in the country, and only about one-third of all law students were in AALS-approved schools. Stevens, supra note 27, at 494-96.

34. The education figures for the 1950-70 judges match those for the bar as a whole. According to a 1970 survey, $73.3 \%$ of all lawyers in the 16 states had college degrees, and $93 \%$ had law school degrees. The figures for lawyers in all 50 states were identical, confirming the representativeness of our sample of 16. See Bette H. Sikes et al., The 1971 Lawyer Statistical Report 8 table 4 (Chicago: American Bar Foundation, 1972).

35. The full list is Cornell, Columbia, Duke, Harvard, Stanford, University of Chicago, University of Michigan, University of Pennsylvania, University of Virginia, Yale. 
ally well regarded nationally; indeed many would be in the first rank today, and some were perhaps regarded as in the first rank earlier in the century. While Rank 1 schools are mostly private, the rank 2 schools are mostly in state universities. They include such law schools as Wisconsin, Minnesota, UCLA, and Vanderbilt. ${ }^{36}$ The third rank includes university law schools with lesser national reputations, regarded more as local schools, such as University of Alabama, South Dakota, Temple, and Wake Forest, and also includes some well-regarded proprietary schools, such as John Marshall Law School and New York Law School. The fourth rank consists of mostly proprietary schools and night law schools, some now defunct.

Over time, as law school education became the norm, displacing training by clerkship, there was an increase in the proportion of judges from each of our four ranks of law schools. But as table 6 also shows, the sharpest increase was in judges who had gone to rank 3 law schools (from $4.4 \%$ of judges in $1900-1920$ to $24.6 \%$ in $1950-70$ ), with graduates of rank 2 schools close behind (from $9.2 \%$ to $24.6 \%$ ).

In proportion to graduates of the other law schools, representatives of the rank 1 schools declined on the state supreme courts (although in absolute terms, they increased). Of judges in 1900-20 who had gone to law school (a minority of about $40 \%$ of all judges), $42 \%$ had gone to law schools of the first rank; of the 1950-70 judges who had gone to law school (by that time, almost all of them), $28.7 \%$ were graduates of rank 1 schools. ${ }^{37}$

Graduates of the proprietary and night law schools (those with the least prestige in the profession) while probably not represented in the ssCs in proportion to their numbers in the legal profession, have certainly not been excluded from the high courts. They accounted for $10 \%$ of all ssc judges in $1900-20$ (almost $25 \%$ of all law school graduates on the courts) and $17 \%$ in 1950-70. It must be emphasized that graduation from a rank 4 law school cannot be equated with lower class origin or poor legal education. The quality of these schools and the nature of their students vary greatly. But generally speaking, these proprietary schools have catered to students from workingclass backgrounds. The presence of their graduates on the courts, along with the increase in judges from rank 3 schools, testifies to the relative openness of

36. The full list of rank 2 law schools is Georgetown, George Washington, Hastings, Indiana University, New York University, Northwestern, Rutgers, State University of New York at Buffalo, University of California at Berkeley, UCLA, University of Illinois, University of Iowa, University of Minnesota, University of North Carolina, University of Southern California, University of Texas, University of Wisconsin, Vanderbilt.

37. Canon, Characteristics and Career Patterns, supra note 3, presents data on the judges sitting on all 50 courts in the period 1961-68 and gives the percentage who attended ten prestigious private law schools. It is the same as our list of rank 1 schools, except that Vanderbilt is substituted for Michigan (a state university). Canon's data show that $16 \%$ of the judges sitting in the 1960 s attended these prestigious law schools (id. at 35). If we exclude the Michigan Supreme Court, with its numerous Michigan law graduates, from our calculations, $24 \%$ of the judges on the other 15 courts in the 1950-70 period attended rank 1 schools, a considerably higher figure than Canon's. One reason is that northeastern states are slightly overrepresented in our sample: in 1950-70,50\% of the Maine court's members attended rank 1 schools, $40 \%$ of New Jersey's, and $36 \%$ of Rhode Island's. Canon notes a similar preponderance of prestigious private law school backgrounds for judges in the Northeast (id. at 35). 
access to sscs. The courts have been staffed by lawyers from a variety of schools-and this diversity increased over the first half of the century. ${ }^{38}$

On the other hand, the SSC bench has been, in some sense, an educational elite. Throughout the century, over $70 \%$ of judges have been college graduates-a higher proportion undoubtedly than for state legislators and probably higher, in the earlier part of the century, than for the bar as a whole. ${ }^{39}$ For the last 50 years, half of the judges were graduates of law schools of the first and second ranks. However, they had not been active legal scholars: of the judges in 1950-70, only $19.6 \%$ had published a legal article or book, ${ }^{40}$ and only $12 \%$ had taught law before their ssc tenure. ${ }^{41}$ But those figures are probably considerably higher than those for members of the bar as a whole.

\section{E. Former Legal Practice}

Almost all ssc judges, including those who had held other public offices, spent at least part of their pre-judicial careers in the private practice of law. The biographical sketches from which our data are drawn do not identify specific type of practice, such as corporate, matrimonial, personal injury, or criminal defense. Two kinds of information were available: whether the judge had practiced on his own or with a firm and whether he had practiced in one of his state's larger cities or in a smaller town. We can compare these data with what is known about the type of practice of lawyers in the aggregate.

In 1900, the American bar consisted mostly of sole practitioners and twoman firms, many in small towns and cities. The mushrooming urban centers, however, already had a sprinkling of larger corporate law firms and a rapidly growing number of struggling sole practitioners. ${ }^{42}$ Precise figures on the distribution of these three major categories-smaller town lawyers, big-city solo lawyers, and big-city firm lawyers-are not readily available. Nevertheless, it seems plain that over the course of this century, there has been a steady drift

38. One could argue that in the last few decades, American law schools, regardless of prestige, have become more alike and that diversity has declined. Nevertheless, the sheer number of schools (with different admissions criteria, tuition levels, and recruitment patterns) has remained large. Access to judgeships has not been dependent on graduating from one of a few elite schools.

39. Whereas $78.3 \%$ of judges sitting in our 16 states during the $1950-70$ period were college graduates, studies in California, New Jersey, Ohio, and Tennessee (in 1957), Iowa (1967), and New Mexico (in 1981) reveal that an average of $53 \%$ of state legislators in those specific years were college graduates. In 1979 , $16 \%$ of the United States population over 25 had graduated from college. See Fred R. Harris \& Paul L. Hain, America's Legislative Process: Congress and the States 57 (Glenview, Ill.: Scott, Foresman \& Co., 1983).

40. For 1900-1920 judges, $14.7 \%$ had published; for $1925-45,11.3 \%$.

41. About $7 \%$ of the $1900-1920$ and the $1925-45$ judges taught law before reaching the court. About $4 \%$ in all three time periods taught law during or after their SSC tenures.

42. See generally, James Willard Hurst, The Growth of American Law: The Law Makers chs. 12-13 (Boston: Little, Brown \& Co., 1950). On the early two-man firm, see Daniel H. Calhoun, Professional Lives in America: Structure and Aspiration, 1750-1850 (Cambridge: Harvard University Press, 1965). Auerbach, supra note 27, provides a polemical account of the growth of urban law firms and contrasts them with the "traditional" legal profession. 
toward an urban bar ${ }^{43}$ and, especially in the last 25 years, toward a bar practicing in law firms. ${ }^{44}$

The nature of a lawyer's practice might be thought to influence legal skills, attitudes toward the law, and hence performance as a judge. Some studies have found that in broad averages lawyers associated with large urban firms, when compared with other groups of urban practitioners, more often were Protestant, from upper middle class families, and graduates of leading national law schools. ${ }^{45}$ Other studies have shown that this same group, serving wealthier clients, by and large, is less tempted to violate the canons of legal ethics and better able to afford careful legal research and writing. ${ }^{46}$ Urban sole practitioners, on the other hand, more often - at least until recentlywere from foreign-born families and graduates of proprietary or part-time schools. Their practice is more likely than that of firm lawyers to be legally unsophisticated. ${ }^{47}$ And they have been thought of as more often involved in politics than firm lawyers, as a way of cultivating contacts and a more secure income. ${ }^{48}$ Less has been written about the smaller town lawyer in the twentieth century. This lawyer has typically practiced alone or in a small partnership, often with relatives. One might expect the small-town lawyer to be more like the urban solo lawyer than the big-city firm lawyer in terms of the legal sophistication of practice. One study shows that small-town lawyers very often are drawn into politics, perhaps more often than big-city solo lawyers. ${ }^{49}$

As table 7 shows, the distribution of judges according to prior legal practice has not quite matched the trends for the bar as a whole. Many judges did not provide adequate information on type of practice. But in the information we do have, the striking feature is the stability of the distribution over time (table 7). In the earlier years of the century, urban lawyers (solo and firm combined) were already strongly represented on the sscs. Of the 1900-1920 judges whose place of practice is known, $41.7 \%$ had practiced in one of the

43. An American Bar Foundation survey showed that by $1948,50 \%$ of lawyers in private practice worked in cities of 200,000 or more. In $1970,62 \%$ practiced in cities of 100,000 or more. Sikes et al., supra note 34 , at 14-19 table 7 .

44. Id. The American Bar Foundation survey shows that in $1949,68.7 \%$ of private attorneys were sole practitioners. By 1970, however, that number had declined to $50 \%$; half of all private practitioners worked in firms. With the growth in numbers of lawyers employed directly by government, corporations, and other organizations, the proportion of all lawyers who were sole practitioners in 1970 was $36.6 \%$.

45. See, e.g., Jack Ladinsky, The Impact of Social Backgrounds of Lawyers on Law Practice and the Law, $16 \mathrm{~J}$. Legal Educ. 127 (1963) (study of Detroit-area lawyers practicing in 1960). But see Robert L. Nelson, The Changing Structure of Opportunity: Recruitment and Careers in Large Law Firms, 1983 A.B.F. Res. J. 109.

46. See Jerome E. Carlin, Lawyers on Their Own (New Brunswick, N.J.: Rutgers University Press, 1962), and id., Lawyers' Ethics: A Survey of the New York City Bar (New York: Russell Sage Foundation, 1966); Erwin Smigel, The Wall Street Lawyer (New York: Free Press of Glencoe, 1964).

47. See Ladinsky, supra note 45, and Carlin, Lawyers on Their Own, supra note 46. These are, of course, statistical generalizations. Many sole practitioners have had lucrative and sophisticated commercial or trial practices and strong educational backgrounds.

48. See Arthur L. Wood \& Walter I. Wardwell, The Lawyer and Community Leadership, 9 J. Legal Educ. 162 (1956). Firm lawyers, on the other hand, appear from Wood and Wardwell's study to be more likely than sole practitioners to be involved in pro bono work with nonpolitical organizations.

49. Id. See also Donald D. Landon, Lawyers and Localities: The Interaction of Community Context and Professionalism, 1982 A.B.F. Res. J. 459. 
largest cities in their state or in the state capital. ${ }^{50} \mathrm{By} 1950-70$, the proportion of city lawyers on SSCs had grown only moderately, to $52.1 \%$. Conversely, former small-town lawyers, who were at least $58.3 \%$ of judges sitting in $1900-1920$, held their own pretty well: $47.9 \%$ of the $1950-70$ judges had been small-town practitioners. ${ }^{\text {s1 }}$

Former urban firm lawyers, while perhaps dominant in bar association politics and legal prestige, have not been significantly represented on SsCs; $9.8 \%$ of 1900-1920 judges had worked in firms, and this figure had grown only to $15.9 \%$ in $1950-70-a$ far smaller increase than that of big-city firm lawyers in the profession at large.

As might be predicted, former urban firm lawyers were more likely than other judges to have attended prestigious law schools. About two-thirds $(65 \%)$ had graduated from rank 1 or rank 2 law schools, ${ }^{52}$ compared with

TABLE 7

Former Private Legal Practice of State Supreme Court Judges, 1900-1970

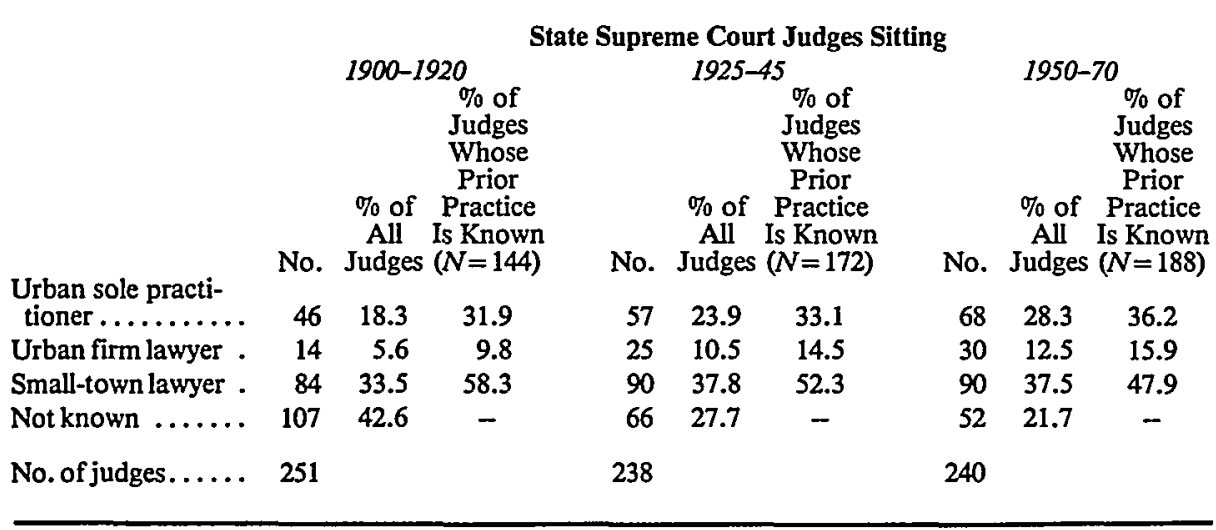

50. We defined urban or city lawyer on a relative basis to account for differences between states and changes over time in the size of cities. City meant (1) one of the three largest cities in the state at each sample year; or (2) any city over 100,000 in population, if there were more than three; or (3) the state capital (if it was not one of the three largest cities). Our goal was to distinguish among types of legal practice within each state.

51. We suspect that most of the large category of judges in table 7 whose former practice is unknown were small-town lawyers, because on measures such as type of law school attended, legal scholarship, and movement from private practice into public office (all discussed later), they resembled known former small-town lawyers much more closely than either urban firm lawyers or urban solo lawyers.

Canon, Characteristics and Career Patterns, supra note 3, using different (more stringent) measures of urban practice, indicates even more former small-town lawyers on the courts in the $1960 \mathrm{~s}$. His data cover judges in all 50 states in the 1961-68 period. In his study, an urban lawyer was defined as one who practiced in a Standard Metropolitan Statistical Area over 100,000 according to the 1960 census. By comparison, our study included as urban a lawyer who practiced in, for example, Boise, Idaho-not a city by Canon's definition, but both the biggest city in the state and the state capital. By Canon's definition, only $30.6 \%$ of judges in 1961-68 had practiced in a city (id. at 37); hence he concludes that former urban lawyers were strongly underrepresented. In our definition, $54.6 \%$ of those we have information about (and $45.5 \%$ of all judges in our 16 states) in the $1960-70$ period were former urban lawyers.

52. The results are rather consistent over time. Of judges who had practiced in city firms, $57.2 \%$ of those sitting in 1900-1920 had graduated from rank 1 or 2 schools, as had 60\% of those sitting in $1925-45$, and $73.3 \%$ of those in $1950-70$. The corresponding figures for former urban solo lawyers were $37 \%, 49 \%$, and $45.5 \%$, and for former small-town lawyers, $22.6 \%, 32.2 \%$, and $48.8 \%$ in $1950-70$.

Judges who had been city firm lawyers were also much less likely than their colleagues to have skipped 
$44 \%$ who had been urban solo lawyers and $35 \%$ who had been small-town attorneys. Former city firm lawyers were also more likely to have displayed an interest in legal scholarship at some point in their careers: $40 \%$ had either taught law or written legal articles or books, compared with $25 \%$ of the judges who had been urban solo lawyers and $20 \%$ of the former small-town lawyers. Thus the failure of urban firm lawyers to reach sscs in proportion to their legal prestige (or even in proportion to their numbers) may have held down the number of judges who were graduates of elite law schools and had a scholarly bent. ${ }^{53}$

On the other hand, judges who had been urban sole practitioners were by no means, as one might expect, predominantly graduates of either less prestigious or proprietary law schools. Of the former city solo lawyers who were judges in 1900-1920,37\% had attended a rank 1 or rank 2 law school, as had $49 \%$ of the $1925-45$ judges and $45.5 \%$ of the $1950-70$ judges who had started out as city solo lawyers. This suggests that many former solo lawyers on the courts did not fit the stereotype-less well educated, of humbler social origin - of "lawyers on their own"' in the big city. They may have come from a class of politically active or otherwise ambitious lawyers who preferred solo to firm practice, regardless of their social and educational backgrounds.

Their routes to the ssc, however, were not necessarily through public office or electoral politics. Only $29 \%$ of former city solo lawyers on the courts had held public office, such as state legislator or district attorney, before entering the judiciary. The corresponding figure for judges who had been urban firm lawyers was $45 \%$; that is, almost half had held public office (primarily as public prosecutors) before becoming judges. The former firm lawyers were by this measure more "political" than the city solo lawyers who became judges.

The large contingent of judges who had started their professional careers as small-town lawyers most often moved through other public offices en route to judicial positions; slightly more than half $(53 \%)$ had done so. Almost $42 \%$ had held elective political office, such as state legislator (compared with $27 \%$ of the former urban lawyers, solo or firm). Many former small-town lawyers $(48.5 \%$ ) had been public prosecutors (many had been both prosecutors and legislators); the comparable former-prosecutor figure for former city solo practitioners was $27 \%$, and $45 \%$ for former urban firm lawyers.

\section{F. Age, Tenure, and Turnover}

State supreme court judges have not been young men. But neither have the

law school entirely in favor of a law office clerkship. At least half of 1900-1920 judges had clerked, but only $14 \%$ of those who had practiced in urban firms had obtained their legal education that way.

53. Judges who graduated from elite law schools (ranks 1 and 2) were more likely to publish legal articles ( $21.6 \%$ had done so) than judges who graduated from rank 3 or 4 schools or had clerked $(11.2 \%)$. The elite-school graduates were more likely to have taught law, however, only among 1900-1920 judges (19.7\% compared to $3.8 \%$ for other judges); this difference disappeared for 1925-45 judges and 1950-70 judges. The correlation between having published and having taught law, incidentally, was rather low-Pearson's $R$ was .04 for 1900-1920 judges, .16 for 1925-45 judges, and .35 for 1950-70 judges. 
courts been dominated by the very old. The judges sitting in the 1900-1970 period first reached the court at an average age of 52 . The average retirement age (excluding those sitting in 1970) was 66 . About $8 \%$ of the judges in this century stayed on the court beyond the age of 80 .

However, there has been a slight trend over the years toward older judges. In our 16 states, the average age at first accession to the court was 50.4 for 1900-1920 judges, 52.75 for $1925-45$ judges, and 53.1 for those sitting in 1950-70. ${ }^{54}$ The average retirement age crept up from 63.5 for 1900-1920 judges to 68.5 for those who sat in the 1925-45 period, and 67.2 in 1950-70.5s In the 1900-1920 period, $10 \%$ of the judges reached the court before they were 40 (J. G. Sweeney reached the Nevada Supreme Court in 1906 at 29, and William T. Faircloth, who retired from the North Carolina Supreme Court in 1900, first reached it in 1876 at age 30 ); $28 \%$ took up a position on the court before they were 45 . But in the $1925-45$ period and the $1950-70$ period, only $4.5 \%$ of the judges were under 40 during their first term, and only $14.5 \%$ were under 45 . Similarly, in $1900-1920,27.4 \%$ of the judges remained on the court beyond the age of 70; in 1925-45 and 1950-70, over $40 \%$ did so.

We computed an average age for the judges sitting on each of the 16 courts at five-year intervals. Based on this calculation, the average age of the judges deciding any particular case in the twentieth century was 61. In 1900-1920, it was 57.8 , in $1950-70,62.3 .{ }^{56}$

As the span between average age at first accession to the court and average age at retirement implies, the tenure of judges has been quite secure. The average judge stayed on the court 14 years. One quarter had a tenure of 20 years or more. ${ }^{37}$ For our three time periods, there have been no significant trends in these tenure figures.

As the figures on tenure suggest, the composition of the courts was rather stable. A litigant before an SSC in the $1900-1970$ period was likely to face a panel of judges with substantial on-the-job experience. Their average tenure on the court, at any given time, would have been 9.7 years. ${ }^{58}$ On the average, only one of three judges would not have been there five years earlier..$^{59}$ The judges have usually had plenty of time to get to know each other. The new

54. Canon's study of judges in all 50 states in 1961-68 shows an average age at first accession to the court of 55.8. Canon, Characteristics and Career Patterns, supra note 3, at 37 .

55. Canon's data, id., show an average retirement age of 72.

56. Canon's data (1961-68, all 50 courts), id., show an average age of 61.7 .

57. In our 16 states, the longevity record was held by Judge W. A. Johnston, who sat on the Kansas Supreme Court from 1884 to 1935 . Charles W. Parker was on New Jersey's Court of Errors and Appeals for 40 years (1907-47). Grafton Green of Tennessee (1910-47) and Lucien D. Gardner of Alabama (1914-51) served for 37 years, and John C. Anderson of Alabama (1904-40) for 36.

58. This average was calculated by computing the mean years of experience for each panel of judges on each court at five-year intervals. For example, the average time since first accession to the court for the three Idaho Supreme Court judges sitting in 1900 was 7.7 years; for those sitting in 1905, 7.3 years; and so on through 1970, a process repeated for all 16 SSCs. These 240 means (15 time points $\times 16$ states) were then averaged.

59. We constructed this "turnover" measure by computing the percentage of "new judges" on each court at five-year intervals; a new judge was one who had not been on the court at the previous sample year (five years earlier). In 1900-1920, 38.5\% of the judges were such new judges (averaging the 16 states); in $1925-45$, the figure was $39.5 \%$, and in $1950-70,35.3 \%$. 
judge, one suspects, moved into an organization that was rather set in its ways and had a stable, strong internal culture.

Finally, as the high average retirement age (66) and 14-year average tenure suggest, these judgeships have been terminal positions for most occupants. The position was rarely used as a steppingstone to other political or judicial offices. Of the judges who sat in 1900-1920 and 1925-45, almost 30\% apparently died in office, according to their Who's Who biographies. About $50 \%$ apparently retired; they mention no activity after their last term of office expired. About $10 \%$ report a return to private practice. A handful taught law. The remaining $10 \%$ went on to hold some other public office: a few were elected to political office (such as Samuel J. Ervin, Jr., a North Carolina Supreme Court judge from 1948 to 1954, who later served in the U.S. Senate); a few moved to posts in the federal judiciary; and some served on governmental councils and commissions. Of the judges who sat on our 16 courts in this century, only two-Mahlon Pitney and William Brennan, both of New Jersey ${ }^{60}$-went on to the United States Supreme Court. By and large, therefore, a lawyer or judge did not take a position on an SSC in order to be promoted further. ${ }^{61}$

\section{JUdicial BACKGROUND AND TeNURE: INTERSTATE DIFFERENCES}

\section{A. Pre-judicial Careers}

Taken as a whole, as we have seen, judges in this century have been drawn almost equally from three broadly conceived career paths: about $35 \%$ had held elective political office (such as state legislator) before entering the judiciary; some $40 \%$ had been law enforcement officials (state or county prosecutors); ${ }^{62}$ and $37 \%$ had held neither type of public office, having gone into the judiciary from private practice.

The judiciary in all states reflects this three-forked pre-judicial career distribution, but there are some striking differences in emphasis. Some states have drawn their judges disproportionately (in relation to the national mean) from the ranks of politicians, some have been especially open to law enforcement officers, while in others, the private-practice route to the court has predominated. At the extremes, for example, over $90 \%$ of the North Carolina judges in the 1925-45 period had held political office (other than district attorney), compared with only $10 \%$ of Michigan judges in that period. Of South Dakota Supreme Court judges in 1950-70, 70\% had been law enforce-

60. Pitney was appointed to the United States Supreme Court in 1912. Brennan was an associate justice of the New Jersey Supreme Court for four years before being appointed to the Court in 1956.

61. There have been, of course, a few well-known appointments of judges from other states, such as Holmes of Massachusetts and Cardozo of New York. But of the other appointments to the Court in this century, only four others had been SSC judges. Three were appointed by Taft in 1909 and 1910: Joseph Lamar of Georgia; Willis Van Devanter, who had been on the Wyoming Supreme Court for one year; and Horace Lurton, who had been on the Tennessee Supreme Court before moving to the federal circuit court of appeals in 1893. Cound, supra note 13. Sandra O'Connor, appointed by President Reagan in 1981, had sat on the Arizona Court of Appeals for two years but not on the Arizona Supreme Court.

62. Fourteen percent had been both prosecutors and elected political officials. 
ment attorneys, contrasted to $25 \%$ of the Tennessee members in those years. Three-quarters of the judges on the California Supreme Court in the 1900-1920 period had held no public office, either political or law enforcement; but only $20 \%$ of Alabama's judges in those years came to the bench from a career in private practice only.

Some states have had erratic recruitment patterns. In Oregon, for example, about $51 \%$ of the judges in the 1900-1945 period had held political office, well over the 16-state mean of $37 \%$. But of the Oregon judges who sat in the 1950-70 period, only 10\% had held political office, compared with a national mean of $29 \%$ for that period..$^{63}$ Nevertheless, we can identify those states in which one of the three prior career patterns consistently predominated.

Table 8 lists the 16 state courts and indicates which prior career predominated among judges in each for the entire period. A state is categorized as "high" in a particular prior career if the proportion of judges having that career exceeded the 16-state mean by at least 10 percentage points in at least two of our three time periods. States with judges whose prior careers were more or less evenly distributed during the three periods were categorized as "mixed," while those in which there were erratic swings in the distribution of prior careers were categorized as "shifting." Table 8 also shows which types of careers have been least frequent among judges selected in a particular state. We consider a state "low" in a career line if the proportion of judges with that background was consistently lower than the 16-state mean by $10 \%$ or more.

The tendency toward selecting judges with political backgrounds was strongest in the states of the Northeast (New Jersey, Rhode Island, and Maine) and the South (Alabama, North Carolina, and Tennessee). In the northeastern states judges were appointed by the executive or the legislature; in the three southern states plus West Virginia, during most of this century, judges were selected by "partisan" elections. But for most of this period our three Deep South states were de facto one-party, so the route to judgeships was nomination by party officials.

Conversely, the states with large proportions of former prosecutors on their courts (and comparatively few who had held other political office) are mostly midwestern and plains states (Michigan, Illinois, Kansas, South Dakota, and to some extent, Minnesota; Nevada also is in this group) with a history of judicial selection by contested elections. ${ }^{64}$

63. Similarly, very few (16.7\%) of the Michigan Supreme Court judges in 1900-1920 came to the bench from a career entirely in private practice (the 16 -state mean then was $40.6 \%$ ). Yet well over half $(57.9 \%$ ) of its judges in 1950-70 did (compared to a national average of $38.3 \%$ ).

64. These states began the century with partisan elections. By 1966, Michigan, South Dakota, Minnesota, and Nevada had switched to nonpartisan elections, although partisanship remained strong in Michigan. In 1958 Kansas adopted a version of the Missouri plan. (In the Missouri plan the judge is first appointed, via a process strongly influenced by the bar association, then, after a term in office, ratified or rejected by the electorate.) Illinois, meanwhile, retained partisan elections for the initial selection of its judges, but by 1966 had instituted "merit" elections (i.e., a Missouri-type plan) for determining their subsequent retention or rejection. Glenn R. Winters, Selection of Judges-An Historical Introduction, 44 Tex. L. Rev. 1081, 1087 (1966). 


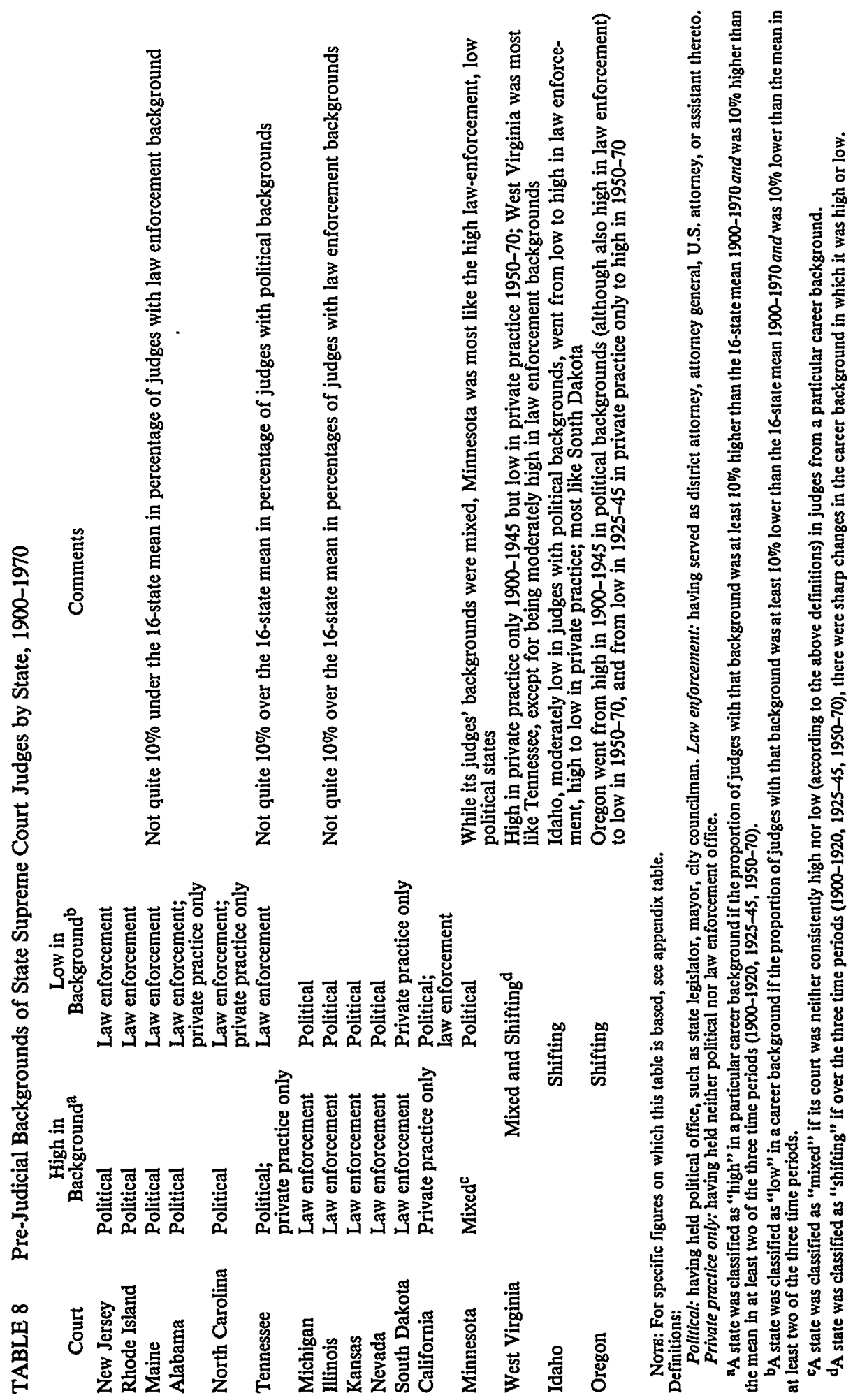


It is difficult to tell to what extent the mode of judicial selection rather than the regional political culture produces these rather sharp differences. ${ }^{65}$ For example, for 70 years California has tended to choose judges without backgrounds in either law enforcement or political office even though its method of selection changed from direct election to a modified Missouri plan. ${ }^{66}$

\section{B. Prior Judicial Experience}

Nationwide, as noted earlier, about $47 \%$ of this century's judges have served substantial lower court judicial apprenticeships-five years or more. There has been considerable variation around this average, however, as shown in table 9. At one extreme, California had a uniquely high average: $79 \%$ of its judges had at least five years of judicial experience when they reached the court. On the other hand, only $25 \%$ of the Kansas Supreme

TABLE 9

State Supreme Court Judges with Five or More Years of Lower Court Experience by State, $1900-1970$

\begin{tabular}{|c|c|}
\hline $\begin{array}{r}1900-1920 \\
\%\end{array}$ & ${ }^{1925-45}$ \\
\hline Cal. ..... 86.7 & Cal. ..... 76.5 \\
\hline Ala...... 75.0 & Ore. .... 71.4 \\
\hline Mich. ... 66.7 & Ill. ...... 68.4 \\
\hline Minn. . . . 66.7 & Ala... .58 .3 \\
\hline Ill. ...... 66.7 & Nev. .... 50.0 \\
\hline 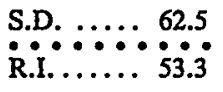 & $\begin{array}{l}\text { R.I. ..... } 50.0 \\
\text { Mich. .... } 47.6\end{array}$ \\
\hline Ore. .... 46.7 & N.C. . . . 46.2 \\
\hline N.C. .... 40.0 & Tenn. .... 44.4 \\
\hline $\begin{array}{l}\text { W. Va. ... } 38.5 \\
\star \star \star \star \star \star \star ~ \\
\text { Tenn. ... } 33.3\end{array}$ & $\begin{array}{ll}\text { Minn. .... } & 40.0 \\
\text { Maine .... } & 37.5\end{array}$ \\
\hline $\begin{array}{l}\text { Idaho } \ldots . .33 .3 \\
\text { Kan. ..... } 30.8\end{array}$ & $\begin{array}{l}\text { N.J. . . . } 35.5 \\
\star \star \star \star \star \star ~ \\
\text { W.Va. . . } 33.3\end{array}$ \\
\hline Me. .... 22.2 & S.D. .... 33.3 \\
\hline N.J. . . . 19.5 & Idaho .... 30.0 \\
\hline Nev. ..... 18.2 & Kan. .... 6.3 \\
\hline Mean $\ldots .47 .5$ & Mean .... 45.5 \\
\hline Median ... 43.4 & Median ... 45.3 \\
\hline
\end{tabular}

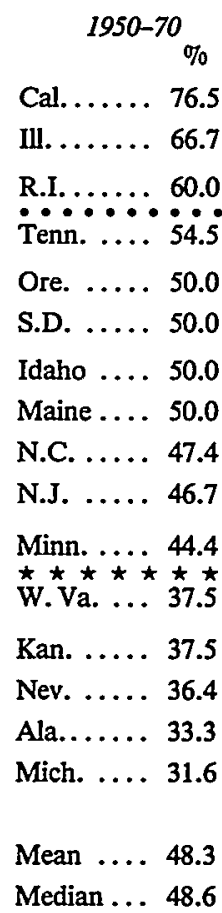

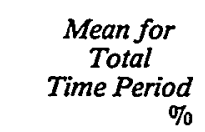

Cal...... 79.4

Ill. ....... 67.3

$\cdots \cdots \cdots$

Ore. .... 56.0

Ala...... 55.5

R.I. ..... 54.4

Minn. .... 50.4

S.D. ... 48.6

Mich. .... 48.6

N.C. . . . 44.5

Tenn. .... 44.1

Idaho $\ldots . .37 .8$

Maine ... 36.6

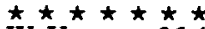

W. Va. ... 36.4

Nev. . . . 34.9

N.J. . . . 33.9

Kan. .... 24.9

Mean .... 47.1

Median ... 46.5

NorE: States above dotted line are more than 10 percentage points above median; states below star line are more than 10 percentage points below median.

65. See Canon, The Impact of Formal Selection Processes, supra note 3.

66. California Supreme Court judges have since 1934 been appointed by the governor, subject to approval by a commission consisting of the attorney general, the chief justice, and the senior presiding courts of appeal judge, and then subject to retention or rejection by the electorate at the next gubernatorial election. 
Court members were "experienced" judges when they reached the court. Of the Kansas judges in 1925-45, in fact, only $6 \%$ had substantial lower court judicial experience.

Only two states, California and Illinois, have been consistently $10 \%$ above the mean in percentage of judges with five years or more of lower court experience; indeed, those two states averaged more than $20 \%$ above the mean. ${ }^{67}$ And only Kansas has been consistently far below the mean, although West Virginia, Nevada, and New Jersey were well below the mean in two of the three time periods.

Sharp shifts over time have not been uncommon. In 1900-1920, $75 \%$ of Alabama's judges had at least five years of lower court experience. This proportion slipped to a still relatively high $58.3 \%$ in $1925-45$, but then to a well below average $33.3 \%$ in $1950-70$. The Michigan court followed a similar course. Tennessee, Idaho, and Maine, all $10 \%$ below the mean in prior judicial experience in 1900-1920, increased their proportion of judges with lower court experience to at least $50 \%$ in 1950-70.

There seems to be little relationship between the predominant type of prejudicial career in a state and the percentage of judges with substantial lower court experience. ${ }^{68}$ Nor did the formal method of judicial selection a state used seem to be related to its judges' amount of lower court experience. In 1950-70 for example, the states highest in prior judicial experience-California, Illinois, and Rhode Island-used, respectively, a modified Missouri plan, partisan election, and legislative appointment. Alabama, which used partisan election, had high levels of prior judicial experience early in the century and ended with a low level, while North Carolina, with a similar system, remained average throughout.

The states that consistently had the highest level of experienced judges among their selections for the court, California and Illinois, had the most extensive system of IACs. Judges in Alabama, which had an IAC system as well, were high in prior judicial experience for the $1900-1945$ period. But the presence of an IAC system does not guarantee the selection of experienced judges, as Alabama's experience in the $1950-70$ period shows. Tennessee, which had an IAC for civil cases for most of the period, was only average in selecting judicially experienced ssC members. New Jersey, which had IACs for law (as opposed to equity) cases from 1900 to 1948 , appointed relatively few experi-

67. California IAC judges, too, typically had served a substantial trial court apprenticeship. See Larry L. Berg et al., The Consequences of Judicial Reform: A Comparative Analysis of the California and lowa Appellate Systems, 28 W. Pol. Sci. Q. 263 (1975); Thomas Y. Davies, Organizational Behavior and the Distribution of Case Outcomes in a California Court of Appeal 36-39 (Ph.D. diss., Northwestern University, 1980).

68. E.g., in states with a high proportion of judges who had held elective political office, two (Rhode Island, Alabama) had a higher than average percentage of judges with five or more years of lower court experience; two (North Carolina, Tennessee) were average; and two (New Jersey, Maine) ranked low in prior judicial experience. The same spread in prior judicial experience occurred in states that tended to select judges with prior careers as public prosecutors. Even when we examine the data separately in three time periods, there is no significant relationship between the predominant prior career among a state's judges and the extent of their prior judicial experience. 
enced judges to its ssc during that period, and only an average number in 1948-70, when it had a modernized court system with many IAC panels.

\section{Judicial Experience and Pre-judicial Careers Combined}

Table 10 combines our data on the prior judicial and pre-judicial experience of the judges. ${ }^{69}$ The addition of the prior judicial experience information produces few changes from table 8 .

The states of the Northeast and South had the highest percentages of judicially inexperienced former politicians-from $24 \%$ to $34 \%$ of all judges on

TABLE 10

Judicial Experience and Pre-Judicial Backgrounds of State Supreme Court Judges by State, $1900-1970$

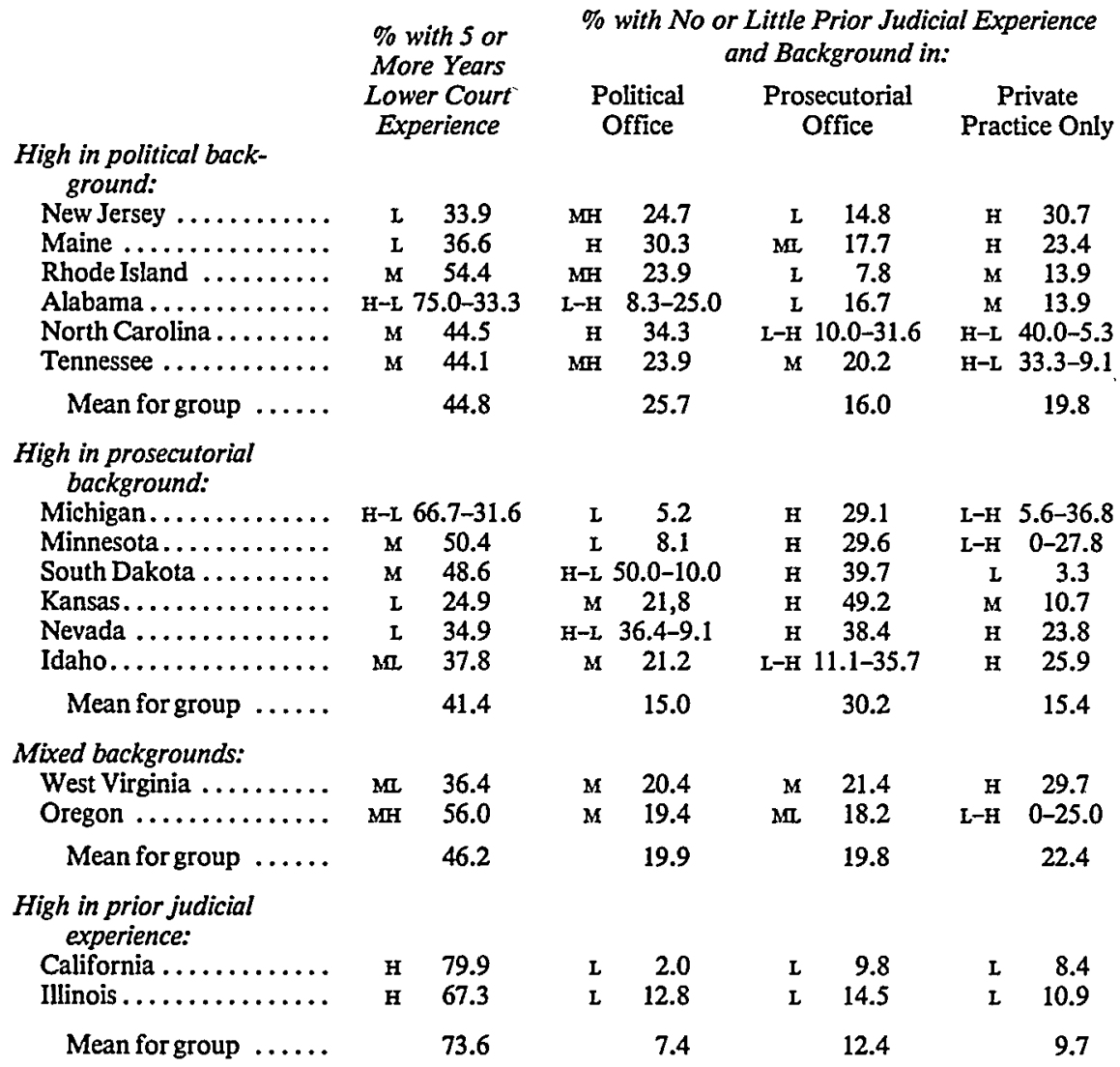

Nore: For "\% with 5 or More Years Lower Court Experience," $H=10 \%$ higher than mean, $L=10 \%$ lower than mean, and $\mathrm{M}=$ mean $\pm 10 \%$. For other types of backgrounds, because the mean was much lower, $\mathrm{H}=5 \%$ over mean, $\mathrm{L}=5 \%$ lower than mean, and $\mathrm{M}=$ mean $\pm 5 \%$. $\mathrm{MH}, \mathrm{ML}=$ moderately high or low (near cutting point). $\mathrm{L}-\mathrm{H}=$ low in $1900-1920$, high in $1950-70 ; \mathrm{H}-\mathrm{L}=$ high in $1900-1920$, low in $1950-70$.

69. The figures in table 10 are averages for all three time periods. 
those courts. ${ }^{70}$ These states also tended to have comparatively few judicially inexperienced former prosecutors-an average of $16 \%$.

The midwestern states in our sample (plus Nevada and, in recent years, Idaho) had the highest proportion of judicially inexperienced former prosecutors on their courts (mostly between $29 \%$ and $40 \%$ of all judges, with Kansas at 49\%). ${ }^{11}$ Those courts also had comparatively low levels of judicially inexperienced former politicians (they averaged 15\%). The major changes from table 8 are the addition of Minnesota to this group and the deletion of Illinois.

Illinois and California had such high proportions of judges with prior judicial experience (67\% in Illinois, $80 \%$ in California) that they were consistently low in all categories of "quick ascenders."

One other pattern or grouping of states emerges from table 10: states with comparatively high levels of judges (averaging $25 \%$ to $37 \%$ of the total) who came quickly to the court without prior judicial careers or careers in public office, that is, primarily straight from private practice. This is a disparate group, including smaller western states (Nevada, Idaho, and Oregon in more recent years); older northeastern states (New Jersey and Maine, but not Rhode Island); West Virginia; and in recent years, Michigan and Minnesota. ${ }^{72}$

\section{Former Legal Practice}

As tables $11 \mathrm{~A}-\mathrm{C}$ indicate, the courts apparently ${ }^{73}$ have varied widely in the types of law practice their judges had engaged in before joining the bench. In North Carolina, West Virginia, Kansas, and South Dakota, over two-thirds of the judges in the 1900-1970 period had practiced in small towns. In California and Rhode Island, on the other hand, comparatively few judges had been small-town lawyers; $60 \%$ were former urban sole practitioners (in California, that figure rose to $80 \%$ in $1950-70$, as the proportion of former small-town lawyers fell from $30 \%$ of judges in 1900-1920 to zero in 1950-70). Most states, however, followed no clear recruitment pattern, either maintaining a mix of urban and small-town lawyers that clustered around the national average for each time period (Tennessee, Alabama, Oregon, Nevada, and Maine fell in this category) or shifting over time from a

70. The proportion of judicially inexperienced former politicians on a court rarely exceeded $35 \%$ of the court in any state for a substantial period. In 1900-1920, New Jersey (41.5\%) and Nevada (36.4\%) exceeded that level. In 1925-45, the leaders were South Dakota (50\%), North Carolina (46.2\%), and Maine and Kansas (both $37.5 \%$ ). In $1950-70$, only North Carolina $(36.8 \%)$ was in this category.

71. The proportion of judges with less than five years of lower court experience and backgrounds in law enforcement exceeded 35\% in the following cases for 1900-1920: Kansas (53.8\%), Nevada (45.5\%), South Dakota (37.5\%); for 1925-45: Kansas (56.3\%), South Dakota (41.7\%); for 1950-70: South Dakota $(40 \%)$, Kansas $(37.5 \%)$, Nevada $(36.4 \%)$, Idaho (35.7\%).

72. The 35\% level for this category was exceeded by North Carolina (40\%), Maine (38.9\%), and New Jersey $(36.8 \%)$ in $1900-1920$; by New Jersey alone $(35.5 \%)$ in $1925-45$, and by Michigan $(36.8 \%)$ in $1950-70$.

73. As noted in table 7, information on prior practice was lacking for $42.6 \%$ of $1900-1920$ judges, $27.7 \%$ of $1925-45$ judges, and $21.7 \%$ of $1950-70$ judges. 
preponderance of one type to another (Idaho, South Dakota, and New Jersey). Levels of urbanization were not wholly predictive of the distribution.

Despite the rise of urban law firms, lawyers who had practiced in firms were sparsely represented on many courts, especially in Michigan and Minnesota, states that did have large cities. In Illinois, downstate small-town lawyers far outnumbered both urban solo practitioners and urban firm lawyers on the court. Only in New Jersey, and there only in the 1950-70 period, did former urban firm lawyers constitute a majority of judges.

\section{E. Legal Education}

Earlier we noted the gradual increase between 1900 and 1970 in the percentage of judges who were educated at rank 1 or 2 law schools. Location of highly ranked law schools seems to have affected interstate variation in this regard (see table 12). Thus, North Carolina, which between 1900 and 1970 found itself with first one, then two, rank 1 or 2 law schools within its borders, went from a below-average percentage of rank 1 or 2 law school gradu-

\section{TABLE 11A}

State Supreme Court Judges Who Were Former Small-Town Lawyers by State (Based on Judges Whose Prior Practice Is Known), 1900-1970

\begin{tabular}{|c|c|c|}
\hline $\begin{array}{r}1900-1920 \\
\%\end{array}$ & $\begin{array}{l}1925-45 \\
\end{array}$ & ${ }^{1950-70} \%$ \\
\hline Idaho.... 83.4 & aKan. .... 75.0 & S.D.... 87.5 \\
\hline aW.Va.... 83.4 & aw.Va... 75.0 & aN.C. ... 85.5 \\
\hline aN.C. ... 80.0 & Ala...... 72.7 & aKan. .... 73.4 \\
\hline alll. . . . . 76.9 & Tenn..... 71.4 & aIll. ...... 66.7 \\
\hline aKan. ... 75.0 & aN.C. . . 70.0 & aw.Va.... 66.7 \\
\hline 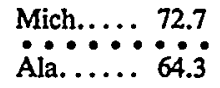 & $\begin{array}{l}\text { alll. ...... } 68.7 \\
\text { Nev...... } 66.6\end{array}$ & $\begin{array}{l}\text { Maine } \ldots: 64.3 \\
\text { Ala....... }\end{array}$ \\
\hline Ore.... 60.0 & S.D..... 63.6 & Tenn.... 55.6 \\
\hline Tenn.... 60.0 & Mich.... 57.1 & Mich.... 50.0 \\
\hline Maine ... 58.2 & Ore..... 54.6 & Idaho.... 46.2 \\
\hline 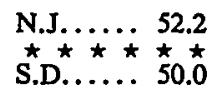 & 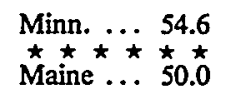 & Nev...... 33.3 \\
\hline Nev...... 50.0 & N.J..... 30.8 & Ore..... 25.0 \\
\hline Minn. ... 44.5 & ${ }^{a}$ Cal. ..... 20.0 & N.J..... \\
\hline${ }^{a} \mathrm{Cal} . . . . .30 .0$ & Idaho.... 12.5 & aCal. ...... \\
\hline aR.I. ..... 12.5 & $\begin{array}{lll}\text { aR.L. . . } 10.0 & \end{array}$ & aR.I. ..... \\
\hline Mean .... 59.6 & Mean .... 53.3 & Mean . ... 47.6 \\
\hline Median ... 60.0 & Median ... 60.4 & Median ... 52.8 \\
\hline
\end{tabular}


ates in 1900-1920 (18.2\%), to an above-average percentage in 1925-45 $(53.9 \%)$, to the highest percentage of any court in the sample during 1950-70 $(89 \%)$. On the other hand, South Dakota ranked high in terms of rank 1 or 2 law school graduates in both 1900-1920 and 1925-45. A law school was not established within South Dakota until 1901, and its judges were more likely to have attended one of the better out-of-state schools. As South Dakota justices during 1950-70 tended increasingly to be graduates of law schools located in or around South Dakota (none of which are among the rank 1 or 2 schools), the court's placement on table 12 as well as the absolute percentage of its judges who attended elite law schools dropped precipitously.

Over all, in the period 1950-70, three of the four courts with the highest percentages of rank 1 or 2 law school graduates (North Carolina, Minnesota, and Illinois) had at least one rank 1 or 2 law school within their borders. ${ }^{74}$ Conversely, there were no such law schools in any of the six states that had the lowest percentages of rank 1 or 2 law school graduates. And in large

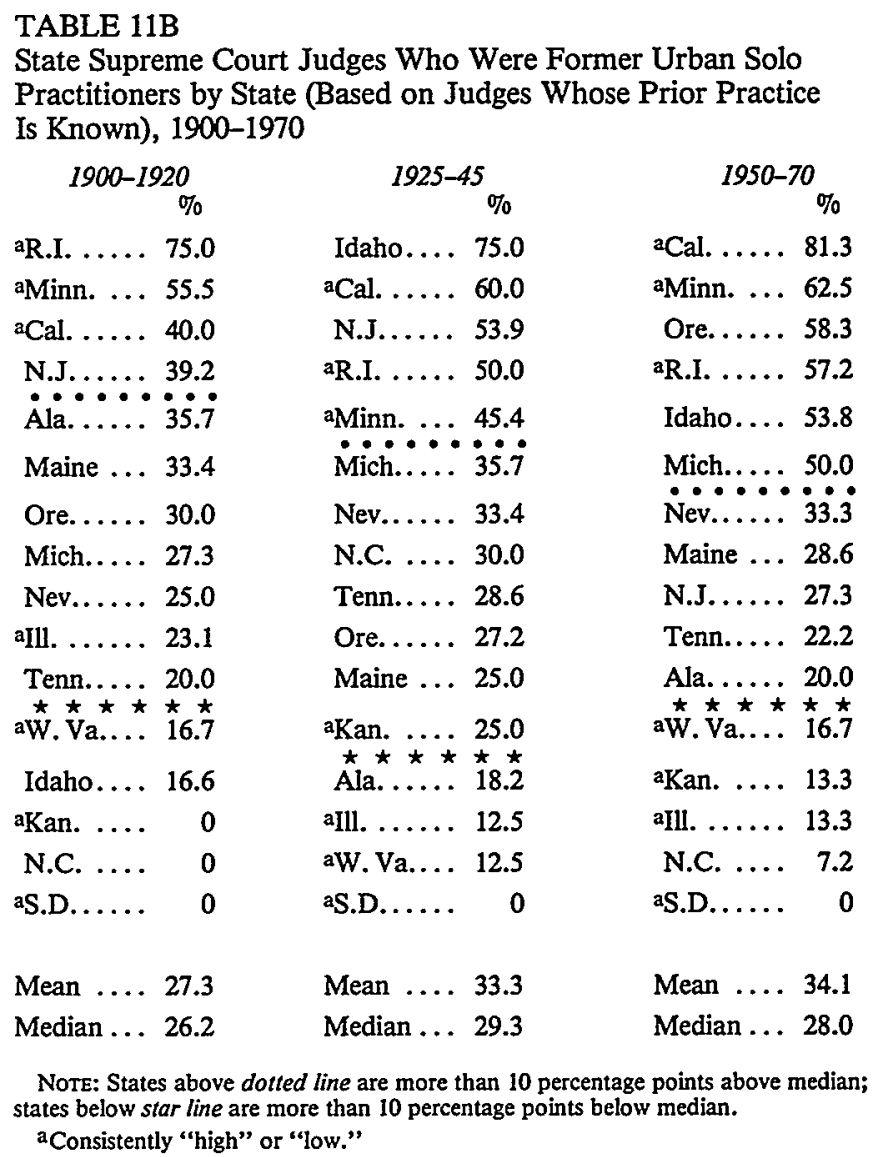

74. The fourth was tiny Rhode Island, surrounded by states with rank 1 law schools. 
states with many law schools, such as California and Michigan, only about half the judges were graduates of the elite law schools.

\section{F. Age, Tenure, and Turnover}

Interstate variations with respect to the average age of sitting justices appear marginal. As table 13 indicates, this is particularly true of 1925-45 and 1950-70, for which the range between the "oldest" courts and the "youngest" courts was 6.8 years and 7.9 years.

Table 14 shows the average turnover rates by state. The figures refer to the average percentage of judges who left the bench during each five-year time period, whether the reason for separation was retirement, electoral defeat, or death. In most cases, the courts exhibit a curvilinear pattern over the three periods. For example, Nevada had a turnover rate of $60 \%$ in $1900-1920-$ highest among the 16 states in our sample. In 1925-45, however, it had the lowest turnover rate $(18.3 \%)$, and in the $1950-70$ period it rose again to the second rank, with a turnover rate of $55.3 \%$. The same pattern was also fol-

TABLE $11 \mathrm{C}$

State Supreme Court Judges Who Were Former Urban Firm Lawyers by State (Based on Judges Whose Prior Practice

Is Known), $1900-1970$

\begin{tabular}{|c|c|c|}
\hline $1900-1920$ & ${ }^{1925-45}$ & $\begin{array}{r}1950-70 \% \\
\%\end{array}$ \\
\hline S.D..... 50.0 & R.I. . . . 40.0 & N.J. . . . 63.7 \\
\hline Cal. .... 30.0 & S.D..... 36.3 & R.I. . . . 42.9 \\
\hline Nev...... 25.0 & Maine . . 25.0 & Nev...... 33.3 \\
\hline Kan. .... 25.0 & Cal..... 20.0 & Tenn..... 22.2 \\
\hline N.C. . . 20.0 & Ill. . . . . 18.8 & Ala. ... . 20.0 \\
\hline Tenn. . . . 20.0 & Ore..... 18.2 & Ill. $\ldots \ldots 20.0$ \\
\hline R.I. $\ldots . .12 .5$ & N.J..... 15.5 & Cal. ..... 18.7 \\
\hline Ore..... 10.0 & Idaho. ... 12.5 & Ore..... 16.7 \\
\hline N.J. . . . . 8.7 & W.Va.... 12.5 & W.Va.... 16.7 \\
\hline Maine $\ldots \underset{\star}{8.4}$ & Ala..... 9.1 & Kan. .... 13.3 \\
\hline Ala..... 0 & aMich.... 7.2 & S.D. . . 12.5 \\
\hline Idaho.... & Kan. .... 0 & N.C. ... 7.2 \\
\hline Ill. ..... & aMinn. ... & Maine ... 7.1 \\
\hline aMich..... & Nev...... & Idaho.... \\
\hline aMinn. ... & N.C. .... & aMich.... 0 \\
\hline W.Va.... & Tenn..... 0 & aMinn. ... 0 \\
\hline Mean $\ldots . .13 .1$ & Mean .... 13.4 & Mean .... 18.4 \\
\hline Median ... 9.4 & Median ... 12.5 & Median ... 16.7 \\
\hline
\end{tabular}


lowed (although to a somewhat less dramatic extent) by Tennessee, Oregon, and New Jersey. Conversely, Idaho, West Virginia, Michigan, California, and South Dakota had low turnover rates in the initial period, high turnover rates in the intermediate period, and low turnover rates in the final period. Two states-Minnesota and Illinois-deviated from the curvilinear pattern by displaying either a continuous increase (Illinois) or decrease (Minnesota) in rate of turnover. Only Rhode Island was relatively devoid of wide fluctuations from one period to the next.

\section{G. Political Party}

In each period, about half the courts were bipartisan in political makeup, composed of substantial numbers of both Republican and Democratic judges. The other half were essentially one-party courts.

As shown in table 15, the Democratic courts of 1900-1920 (North Carolina, Alabama, and Tennessee) remained Democratic in 1925-45 and 1950-70. Some bipartisan courts in the earlier period (New Jersey, Idaho, and Illinois) stayed that way throughout, while Oregon, Maine, and Minnesota tipped, in

TABLE 12

State Supreme Court Judges Attending Rank 1 or Rank 2 Law Schools by State, 1900-1970

\begin{tabular}{|c|c|c|c|c|c|}
\hline $\begin{array}{r}1900-1920 \\
\%\end{array}$ & No. & $\begin{array}{r}1925-45 \\
\%\end{array}$ & No. & $\begin{array}{r}1950-70 \\
\%\end{array}$ & No. \\
\hline Mich. .... 50.0 & 18 & R.I..... 75.0 & 12 & N.C. .... 89.0 & 19 \\
\hline S.D. .... 50.0 & 8 & Minn. .... 73.4 & 15 & R.I. ..... 82.9 & 11 \\
\hline Ill. ....... 38.9 & 18 & Nev. ..... 66.7 & 6 & Minn. .... 77.8 & 18 \\
\hline N.J. $\because \cdots 34.2$ & $\begin{array}{l}41 \\
\because 6\end{array}$ & S.D. $\ldots \ldots, 58.3$ & 12 & Ill. $\ldots \ldots, \because 72.2$ & 18 \\
\hline Cal...... 31.3 & 16 & Mich. .... 57.1 & 21 & Maine .... 65.0 & 20 \\
\hline Nev. ..... 27.3 & 11 & $\stackrel{N . C .}{ }: \ldots, 53.9$ & 13 & Tenn. .... 64.7 & 11 \\
\hline R.I. .... 25.1 & 16 & Ill. ...... 42.2 & 19 & Nev. .... 63.7 & 11 \\
\hline Kan. ..... 23.1 & 13 & Cal...... 41.1 & 17 & N.J. .... 60.0 & 15 \\
\hline Idaho $\ldots . .22 .2$ & 9 & Maine .... 41.2 & 17 & Cal...... 52.9 & 17 \\
\hline N.C. ..... 18.2 & 11 & Tenn. ... 40.0 & 10 & Mich. ... 52.6 & 19 \\
\hline Tenn. .... 15.4 & 13 & 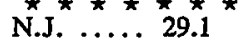 & 31 & Ore. $^{\star \star} \ldots \ldots{ }^{\star} 45^{\star} .0^{\star}$ & ${ }^{\star}{ }_{20}^{\star}$ \\
\hline W. Va. $\ldots 15.4$ & 13 & Ore. .... 28.5 & 14 & W.Va. ... 25.0 & 8 \\
\hline Ore. .... 6.7 & 15 & Idaho $\ldots . .20 .0$ & 10 & S.D. . . . 20.0 & 10 \\
\hline Maine .... 5.3 & 19 & Kan. ..... 12.6 & 16 & Idaho $\ldots . .14 .3$ & 14 \\
\hline Ala....... & 15 & W. Va. ... & 12 & Kan. ..... 12.5 & 16 \\
\hline Minn. .... & 15 & Ala....... & 13 & Ala....... $\quad 0$ & 13 \\
\hline Mean .... 22.7 & & Mean .... 40.2 & & Mean .... 49.9 & \\
\hline Median ... 22.7 & & Median ... 41.3 & & Median ... 56.5 & \\
\hline
\end{tabular}

NoTE: States above dotted line are more than 10 percentage points above median; states below star line are more than 10 percentage points below median. 
one or both subsequent periods, to $85 \%$ or more Republican. Kansas and South Dakota courts remained solidly Republican throughout the century, but Michigan, Rhode Island, and California-Republican in 1900-1920moved toward political division. West Virginia's court showed the widest swing, from predominantly Republican in 1900-1920 to all Democratic in 1950-70.

\section{OPINION CHARACTERISTICS/JUdICIAL BACKGROUND CORRELATIONS}

Earlier publications stemming from this research project demonstrated that during the 1940-70 period, courts with a great deal of case-selecting discretion that wrote comparatively few full opinions (such as California, New Jersey, and West Virginia) tended to reverse lower court decisions more often, write more dissents, publish longer and more citation-laden opinions, and issue declarations of unconstitutionality more often than courts in states without IACs and courts with larger opinion-loads. ${ }^{75}$ But court structure and caseload did not wholly determine case outcomes and opinion style. The

TABLE 13

Average Age of State Supreme Court Judges by State, 1900-1970

\begin{tabular}{|c|c|c|c|c|c|}
\hline $\begin{array}{r}1900-1920 \\
\text { Age }\end{array}$ & No. & $\begin{array}{r}1925-45 \\
\text { Age }\end{array}$ & No. & $\begin{array}{r}1950-70 \\
\text { Age }\end{array}$ & No. \\
\hline Maine . . . 63.6 & 40 & Ill. ...... 65.0 & 35 & N.C. . . 66.6 & 37 \\
\hline N.C. . . . 63.4 & 25 & Ore. .... 64.5 & 36 & Cal..... 65.7 & 35 \\
\hline R.I. . . . . 60.7 & 31 & N.J. $\ldots \ldots 63.9$ & 78 & W. Va. ... 64.5 & 23 \\
\hline Ill. . . . . 60.6 & 36 & Ala...... 63.5 & 36 & R.I. . . . . 63.9 & 25 \\
\hline Mich. $\ldots 60.1$ & 39 & Cal...... 63.3 & 36 & Tenn. .... 63.5 & 22 \\
\hline Cal...... 59.5 & 36 & Minn. ... 62.8 & 32 & Maine .... 62.7 & 31 \\
\hline N.J. . . . 58.5 & 83 & Tenn. ... 62.7 & 25 & Ala...... 62.5 & 35 \\
\hline S.D. ..... 58.2 & 21 & Nev. . . . 62.7 & 16 & Nev. .... 62.3 & 18 \\
\hline Tenn. .... 57.3 & 24 & Mich. ... 62.6 & 43 & Mich. . . . 61.7 & 40 \\
\hline W. Va. ... 56.9 & 26 & Kan. .... 62.3 & 37 & Minn. ... 61.3 & 39 \\
\hline Kan. ..... 56.8 & 33 & Maine ... 61.9 & 37 & N.J. . . . 61.2 & 36 \\
\hline Minn. . . . 56.7 & 27 & N.C. . . 60.8 & 30 & Ore. .... 61.1 & 42 \\
\hline 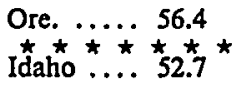 & $\begin{array}{l}27 \\
\star \star \star \\
15\end{array}$ & $\begin{array}{l}\text { Idaho .... } 60.3 \\
\text { R.I. ..... } 58.8\end{array}$ & $\begin{array}{r}23 \\
26\end{array}$ & $\begin{array}{l}\text { S.D. . . . } 61.0 \\
\text { Ill. . } \ldots \ldots 660.6\end{array}$ & $\begin{array}{r}26 \\
33 \\
?\end{array}$ \\
\hline Ala...... 52.5 & 32 & S.D. .... 58.6 & 25 & Kan. .... 59.3 & 36 \\
\hline Nev. .... 50.5 & 15 & W.Va. ... 58.2 & 26 & Idaho $\ldots . .58 .7$ & 24 \\
\hline $\begin{array}{ccc}\text { Mean } \ldots . .57 .8 \\
\end{array}$ & & Mean ... 62.0 & & Mean .... 62.3 & \\
\hline Median ... 57.8 & & Median ... 62.7 & & Median ... 62.0 & \\
\hline
\end{tabular}

Note: For states above dotted line, the average age of judges was 60 or older; for states below star line, the average age of judges was below 55 . 4.

75. Kagan et al., The Evolution of State Supreme Courts, supra note 4, and Friedman et al., supra note 
Tennessee Supreme Court, for example, although buffered from impossible caseloads by an IAC system, almost always issued unanimous opinions. Nor did huge caseloads deter a high rate of dissent in the Michigan Supreme Court in the 1960s. ${ }^{76}$ The Idaho Supreme Court had a much higher dissent rate than other small-state, low caseload courts, ${ }^{77}$ and its opinions more often cited many prior cases, ${ }^{78}$ but it was much less prone to issue declarations of unconstitutionality in cases involving constitutional issues. ${ }^{79}$ Thus,

TABLE 14

Turnover of State Supreme Court Judges by State, 1900-1970

$1900-1920$

Average \%

Leaving

Court During

Each 5-Year

Time Period

Nev....... 60.0

Minn...... 47.3

Tenn........ 44.0

Ala. ...... 43.4

Idaho ..... 40.0

Ore. ..... 39.9

Ill. ...... 39.8

W. Va..... $\quad 38.7$

Kan....... $\quad 38.4$

N.J. . . . . . 37.9

Maine .... 36.4

Mich. ..... $\quad 34.8$

R.I. ..... 32.7

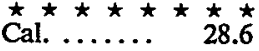

N.C...... 28.0

S.D. ...... 26.7

Mean ..... $\quad 38.5$

Median .... 38.55
1925-45

Average \%

Leaving

Court During

Each 5-Year

Time Period

Idaho ... 49.9

Cal. ..... $\quad 43.9$

Ill. ...... 42.1

W. Va. ... 42.0

S.D. … 40.0

N.C. . . . $\quad 38.8$

Minn. ... $\quad 36.6$

Mich. ... $\quad 35.0$

Maine .... $\quad 31.3$

Kan. .... 29.7

Ore. ..... 29.5

N.J. . . . . 28.8

Tenn. .... 28.0

R.I. .... 27.3

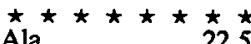

Nev. ..... $\quad 18.3$

Mean .... 33.9

Median ... $\quad 33.2$
1950-70

Average \% Leaving Court During Each 5-Year Time Period

Maine .... $\quad 58.4$

Nev. ..... 55.3

Ill. ...... 47.8

Idaho .... 45.3

Tenn. .... 40.0

N.C. . . . $\quad 35.7$

Ore. .... 35.5

N.J. .... 35.0

Minn. .... 30.6

Mich. .... 30.2

Kan. ..... 29.8

R.I. ..... 28.0

Cal...... 26.4

Ala.......

S.D. .... 22.7

W. Va. ... 20.0

Mean .... $\quad 35.3$

Median ... $\quad 32.8$

NoTE: States above dotted line are almost $10 \%$ or more above median; states below star line are almost $10 \%$ or more below median.

76. The Michigan Supreme Court issued nonunanimous opinions in $44.4 \%$ of the cases we sampled in 1960,1965 , and 1970, compared to a 16-state mean of $16.5 \%$. Friedman et al., supra note 4, at table 5 . For the dedicated reader of these statistics, we should note that in the table just cited in Friedman et al., the figures for Tennessee and West Virginia were inadvertently reversed.

77. Idaho's dissent rate in 1940-70 was $22.3 \%$ of sampled cases, compared to a small-state mean, excluding Idaho, of $8.4 \%$.

78. In 1940-70 the Idaho Supreme Court cited nine or more prior cases in $69.8 \%$ of its sampled opinions compared to a 16 -state mean of $54 \%$ and a small-state mean, excluding Idaho, of $42 \%$.

79. In 1940-70, in all the sampled cases in which constitutional issues were raised, the Idaho court failed to support the claim of unconstitutionality, compared to a 16 -state mean of $19.4 \%$ and a mean of $30 \%$ in the high-discretion courts and in Michigan and Minnesota. 
even if court structure and caseload size influence the nature of decisions and opinion style, there clearly is room for other factors in explaining intercourt variation, such as state-specific legal doctrine, the leadership qualities or the contentiousness of individual judges, ${ }^{80}$ and the "judicial culture" of particular courts. The latter may be influenced by the variations in characteristics of the judges, discussed in the preceding section of this paper.

In this section, accordingly, we will examine correlations between the predominant background of judges on the 16 courts (such as prior career and education) and selected opinion characteristics (such as length, dissent, and citation rates). Table 16 displays the direct rank-order correlations between "judge variables" and "case variables," focusing on the 1950-70 period. The "northwest" cell, for example, expresses the correlation between (a) each court's rank according to percentage of judges in 1950-70 who attended rank 1 and rank 2 law schools (see table 12 above) and $(b)$ each court's rank according to the frequency with which it declared a statute or practice unconstitutional in cases presenting such issues. If the rankings had been identical, with, for example, North Carolina first on both rankings, Rhode Island second, Minnesota third, and so on, the reported correlation would be 1.0 . A

TABLE 15

Ratio of Republican to Democratic State Supreme Court Judges by State, $1900-1970^{\text {a }}$

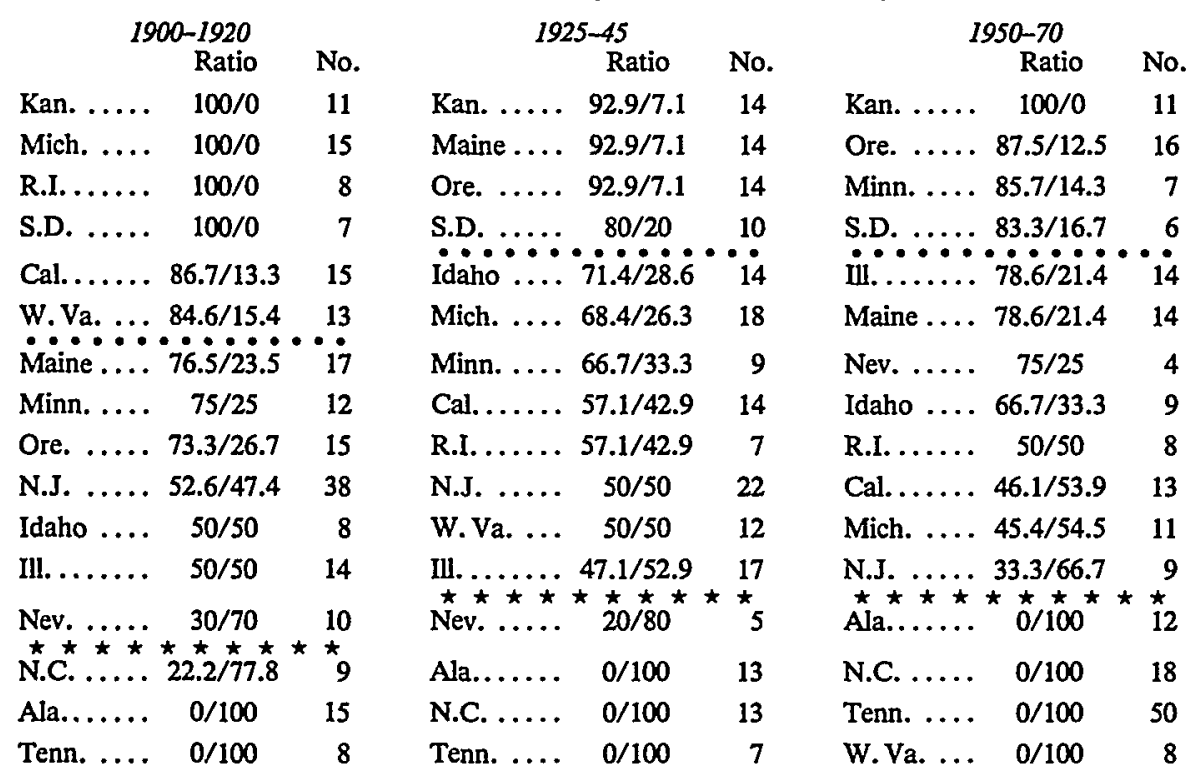

NoTE: On courts above dotted line, 80-100\% of judges were Republican; on courts below star line, 80-100\% were Democrats. North Carolina is placed below the star line for $1900-1920$ because it closely approached $80 \%$ Democratic.

aExcludes judges who mentioned third parties or no political party in their biographies. 
finding of no relationship between the two variables would produce a correlation of zero. If courts with many elite law school graduates were systematically more reluctant to issue rulings of unconstitutionality, the correlation would be a negative number, such as -.75 . In fact, the correlation was .19, indicating a very weak positive relationship between the two variables.

Indeed, all rank-order correlations on table 16, save one (the correlation between "judge turnover" and "\% judgment for criminal defendant"), were between .5 and -.5 , indicating either no systematic relationship, or only weak and inconsistent relationships, between courts' rankings on the judge variables and their rankings on case variables. Thus, while some courts with high proportions of former prosecutors on the bench (Illinois, Nevada) ranked very low in tendency to decide in favor of criminal defendants, ${ }^{81}$ South Dakota's court, $90 \%$ of whose judges were former prosecutors, nevertheless ranked slightly above average (seventh out of 16 courts) in ruling for criminal defendant appellants. The Idaho court, too, second in percentage of former prosecutors, was about average in criminal case rulings in favor of defendants.$^{82}$ Hence the 16-state rank-order correlation between the judge variable (percentage of former prosecutors) and the case variable (percentage of decisions favoring criminal defendants) was a virtually nonexistent $-.11 . .^{83}$

TABLE 16

Rank-Order Correlations for 16 State Supreme Courts, 1950-70

\begin{tabular}{|c|c|c|c|c|c|c|}
\hline \multirow[b]{2}{*}{ Judge Variables } & \multicolumn{6}{|c|}{ Case Variables } \\
\hline & $\begin{array}{l}\text { \% Consti- } \\
\text { tutional }\end{array}$ & $\begin{array}{l}\text { Mean } \\
\text { Opinion } \\
\text { Length }\end{array}$ & $\begin{array}{l}\text { Dissent } \\
\text { Rate }\end{array}$ & $\begin{array}{l}\% 9 \text { or } \\
\text { More } \\
\text { Citations }\end{array}$ & $\begin{array}{l}\text { Reversal } \\
\text { Rate }\end{array}$ & $\begin{array}{l}\text { \% Judg- } \\
\text { ment for } \\
\text { Criminal } \\
\text { Defendant }\end{array}$ \\
\hline $\begin{array}{l}\text { Rank } 1 \text { and } 2 \text { law school } . . . \\
\text { Percentage former prosecu- }\end{array}$ & +.19 & -.23 & -.29 & -.21 & +.06 & -.22 \\
\hline $\begin{array}{c}\text { tors } \ldots \ldots \ldots \ldots \ldots \ldots \ldots \\
\text { Percentage former noliti- }\end{array}$ & -.24 & -.08 & +.12 & +.09 & +.11 & -.11 \\
\hline 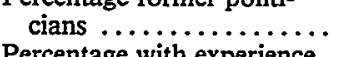 & -.20 & -.02 & -.18 & +.37 & +.46 & +.26 \\
\hline $\begin{array}{l}\text { Percentage with experience } \\
\text { on lower court........... }\end{array}$ & -.14 & -.34 & -.06 & -.05 & +.38 & -.10 \\
\hline $\begin{array}{l}\text { Turnover ................ } \\
\text { Political party consensus ... } \\
\text { Percentage small-town law- }\end{array}$ & $\begin{array}{l}-.28 \\
-.42\end{array}$ & $\begin{array}{l}-.25 \\
-.15\end{array}$ & $\begin{array}{l}-.30 \\
-.36\end{array}$ & $\begin{array}{l}-.09 \\
+.07\end{array}$ & $\begin{array}{l}-.34 \\
+.04\end{array}$ & $\begin{array}{l}-.66 \\
-.28\end{array}$ \\
\hline yers $\ldots \ldots \ldots \ldots \ldots \ldots$ & -.24 & -.11 & -.19 & -.06 & -.01 & -.32 \\
\hline
\end{tabular}

81. The Illinois Supreme Court, $55.6 \%$ of whose judges in $1950-70$ were former prosecutors, ranked fifteenth in decisions for criminal defendants in that period, deciding in their favor in only $17.2 \%$ of sampled cases, compared to a 16-state mean of $30.5 \%$. Nevada, fourth in percentage of former prosecutors, was thirteenth in decisions in favor of criminal defendants $(20 \%)$.

82. South Dakota, which ranked first in number of former prosecutors on the court in 1950-70, supported the criminal defendant in $35 \%$ of sampled cases, and Idaho did in $30.8 \%$.

83. The correlation was also reduced by the fact that the Maine Supreme Court, which ranked sixteenth in former law enforcement officials, had no corresponding propensity to rule in favor of criminal defendants, ranking fourteenth in that measure. And Kansas, ranking eighth in number of former prosecutors (about average) was sixteenth in deciding for criminal defendants, ruling in their favor in fewer than 10\% of sampled criminal cases in 1950-70. 
The correlation between percentage of former small-town lawyers on a court and its comparative propensity to favor criminal defendants was -.32 , but a closer look at the data suggests that even a rank-order correlation in that range is not impressive. Three of the courts dominated by former smalltown practitioners (Maine, Illinois, Kansas) ranked at the bottom of the 16 courts in favoring criminal defendants in 1950-70. But three others with mostly former small-town lawyers (West Virginia, South Dakota, and North Carolina) ranked fourth, seventh, and eighth out of 16 in ruling for criminal defendants, while Michigan and Alabama, slightly above the median in percentage of former small-town lawyers ( 60 and $66 \%$ respectively) ranked second and third in ruling for criminal defendants. Clearly, only correlations well above .5 would be truly significant. And the one "high" correlation ( - .66) on table 16 may be meaningless: it suggests that courts with lower judicial turnover (more stable membership) were more likely to favor criminal defendants. But since we discern no persuasive explanation for that correlation, we can only conclude that it is spurious, not causative.

Some of the correlations in the .3 to .4 range, although not powerful, are suggestive, especially when we examine the data more closely. For example, the relationship between "political party consensus" and "dissent rate" is -.36 , suggesting a weak tendency for courts with judges from a single political party to maintain consensus better than courts with judges from different parties. But the relationship is really a bit stronger: among the five courts whose judges approximated a 50-50 Democrat-Republican split in the 1950-70 period, four of them-New Jersey, California, Michigan, and Idaho-had the four highest nonunanimous opinion rates. The overall correlation was "held down" because (a) Rhode Island, although equally divided between Republicans and Democrats, was traditionally a dissent-suppressing court ${ }^{84}$ and ranked thirteenth in dissent in 1950-70, and (b) West Virginia, $100 \%$ Democratic, nevertheless ranked high in dissent rate, probably because of its high level of case-selecting discretion. ${ }^{85}$

Similarly, the relationship between political party consensus and declarations of unconstitutionality would be slightly stronger than the indicated -.42 if we set aside West Virginia and Tennessee, which had all-Democratic courts but still ranked high in rulings of unconstitutionality (here, too, be-

84. In every decade from 1870 to 1960 , sampled cases from the Rhode Island court revealed a nonunanimous opinion rate of less than $4 \%$. In 1960, 1965, and 1970, however, that figure rose to $11.1 \%$.

85. In West Virginia, the high dissent-rate ranking, despite high political party consensus, might be attributed to court structure: the West Virginia court, like that in New Jersey and California, had full caseselecting discretion, enabling and encouraging it to select the most difficult and controversial appeals. The hypothesis is that court structure outweighs political party consensus/dissensus in stimulating dissent. Thus, too, Rhode Island, despite party dissensus, could have a low dissent rate because it lacked caseselecting discretion and had a high proportion of routine, noncontroversial cases. But consider the Tennessee Supreme Court, which had a partial IAC buffer and some case-selecting discretion yet ranked last in nonunanimous opinions (only $3.3 \%$ for 1950-70). Tennessee's judges were all Democrats. Did party consensus outweigh court structure? We are less inclined to explain Tennessee's low dissent rate in terms of party consensus than in terms of a century-old "judicial tradition" of nondissent that survived changes in court structure. This is similar to the case of Rhode Island, where a low dissent rate has persisted despite political party division on the court. 
cause of jurisdictional rules that gave them discretion to select only persuasive constitutional claims). ${ }^{86}$ Thus the data provides some support for the notion that courts divided by party will more likely be contentious internally and more likely strike down actions by other units of government.

The .38 correlation between percentage of judges with lower court experience and reversal rate implies that courts containing fewer judges with trial court experience have some tendency to be more deferential toward lower court judges, but again, the relationship is not very strong. ${ }^{87}$

Turnover on a court might be expected to affect dissent rates in one of two ways: $(a)$ the newcomers, bringing in new ideas, might engender a higher level of divisiveness, or $(b)$ the newcomers, unsure of their new roles, might follow the lead of the elder brethren, at least for their first few years, thus reducing dissent rates. The correlation $(-.3)$ between turnover and dissent rate in table 16 seems to provide slight support for the hypothesis that higher turnover courts have lower dissent rates, but there are enough anomalies (high turnover states with higher than average dissent rates) ${ }^{88}$ that we believe the effect of turnover is probably inconsistent, or at least cannot be discerned from our relatively crude data.

Courts with more former politicians had no pronounced tendency toward greater deference to legislatures, as expressed in lower propensity to declare laws unconstitutional (the correlation was a weak - .2). And despite a .46 correlation on table 16, if we disregard courts with high case-selecting discretion (California, New Jersey, West Virginia, and Tennessee), the courts with the most former politicians (except North Carolina) had below-average reversal rates, suggesting that political experience, in itself, does not incline judges toward greater activism in overturning lower court rulings or established doctrine.

As noted earlier, courts with case-selecting discretion, on average, wrote fewer but longer opinions in the 1950-70 period, had higher dissent and reversal rates, issued more declarations of unconstitutionality, and found more often for criminal defendants. Nevertheless, there were differences among high-discretion/low-caseload courts. Unlike California, New Jersey, and West Virginia, the Tennessee court wrote short opinions with comparatively

86. Another "outlier" that reduced the correlation was the Minnesota court, which ranked fourth in unconstitutionality rulings (second, if we eliminate courts with high case-selecting discretion), but was almost entirely (86\%) Republican, 1950-70.

87. In 1950-70, Kansas, Nevada, Alabama, and Michigan courts, which ranked lowest in proportion of judges with five years of lower court experience, ranked sixth, fifteenth, twelfth, and thirteenth in reversal rates. But Illinois and Rhode Island, second and third in prior judicial experience, also had belowaverage reversal rates. The courts with high case-selecting discretion (California, New Jersey, West Virginia, and Tennessee) had high reversal rates regardless of level of prior judicial experience.

88. Idaho, for example, with a $45 \%$ average turnover rate for judges in each five-year period 1950-70, ranked fourth of the courts in dissent. When we set aside courts with a strong tradition of nondissent (Maine, Rhode Island, Alabama, and Tennessee) and those with case-selecting discretion (which seems to encourage dissent) (California, New Jersey, and West Virginia) in order to isolate more clearly the influence of turnover, the relationship remains only very weakly in the direction of high turnover-lower dissent. 
few citations. ${ }^{89}$ Unlike California and New Jersey, the Tennessee and West Virginia courts infrequently cited law reviews. ${ }^{90}$ Whereas the New Jersey and California courts were often cited by out-of-state courts, Tennessee and West Virginia were not.91 These differences among courts with similar jurisdictional structures raise the question of whether differences in judges' backgrounds account for the variations in opinions. Among these four courts, however, there were no consistent differences in educational background, at least at the gross level of measurement employed in this study: only $25 \%$ of West Virginia judges sitting in 1950-70 had attended rank 1 or 2 law schools, compared to $60 \%$ in New Jersey and $53 \%$ in California, but $64.7 \%$ of Tennessee judges attended such well-regarded "national" law schools. Nor were there consistent differences between New Jersey and California, on one hand, and Tennessee or West Virginia, on the other, in percentage of judges with backgrounds in politics, in law enforcement, or in lower court judicial experience. Two differences do emerge. At least half the West Virginia and Tennessee judges in the 1950-70 period had been small-town lawyers earlier in their careers, compared to only $9 \%$ of New Jersey judges and no California judges. Second, both New Jersey and California courts were divided between Republicans and Democrats, while the Tennessee and West Virginia courts were one-party (Democratic) courts. Nevertheless, while these differences are suggestive, perhaps more so than the direct correlations discussed earlier, we would be hesitant to attribute too much weight to small-town background and party dissensus in affecting court behavior. The Rhode Island and Maine courts differed markedly on those dimensions but were generally similar with respect to most case-outcome and opinion-style variables. ${ }^{92}$

\section{Conclusion}

In general, the associations in our data between judge characteristics and decision characteristics (dissent rate, opinion style, and so on) are not impressive. Court structure (case-selecting discretion, existence of IACs), court

89. In our 1950-70 sample, California Supreme Court opinions averaged 6.2 pages; New Jersey, 6.8 pages; and West Virginia, 6.7 pages-qualifying them as the three wordiest of the 16 courts; the Tennessee Supreme Court's opinions averaged only 4.4 pages, shortest of the 16 states. Almost $81 \%$ of the New Jersey court's opinions contained nine or more citations to court cases, as did $74 \%$ in California and $71 \%$ in West Virginia; the Tennessee Supreme Court cited nine or more cases in only $36.7 \%$ of its opinions-fifteenth of the 16 courts.

90. In a 1940-70 sample of cases, $19.6 \%$ of New Jersey and $17.5 \%$ of California Supreme Court opinions cited law review articles (putting them first and second among the 16 states in that regard), whereas only $3.4 \%$ of Tennessee and $3 \%$ of West Virginia Supreme Court cases did so (eleventh and thirteenth among the 16 courts).

91. On average, each California Supreme Court opinion in the $1940-70$ period was cited 4 times by outof-state courts and each New Jersey opinion, 3 times, compared with a 16-state mean of 1.5 times. The average Tennessee opinion was cited 1.2 times by out-of-state courts, and the average West Virginia opinion, 0.7. Kagan et al., The Evolution of State Supreme Courts, supra note 4, at 992 table 5. See also Friedman et al., supra note 4, at 806, and Gregory A. Caldeira, On the Reputation of State Supreme Courts, 5 Pol. Behav. 83 (1983).

92. The one sharp difference is that the Rhode Island court, as compared with Maine's, ruled far more often in favor of criminal defendants in the 1950-70 period. Rhode Island's court was evenly divided between Democrats and Republicans, while Maine's was predominantly Republican. 
traditions (such as avoiding split opinions), and the ideas of a strong leader seem considerably more important than whether the court's membership was stable or whether the judges were predominantly former prosecutors or small-town lawyers, or seasoned on lower courts, or educated in highly ranked law schools.

That does not mean that judicial background is unimportant, however. It means only that its importance cannot be ascertained by the method employed here: broad comparisons of court "group portraits" over broad time periods, and simple correlations with gross measures of decision outcomes and opinion style. Sscs, after all, are small groups, in which individual judges' idiosyncratic attitudes, skills, and personalities bulk large. The influence of a judge's prior experience on decision-making and opinion-writing style is affected by intervening factors, such as nature and volume of the court's caseload, the way law clerks and opinion writing are organized, ${ }^{93}$ the influence of intellectually powerful or congenial fellow judges, ${ }^{94}$ and the perceived political mood of the times. 95

The influence of judicial background on decision making, therefore, may be disclosed only (as James Gibson has argued) ${ }^{96}$ by analyses that make the individual judge, rather than the court, the unit of analysis, taking other influences on decisions into account as well. Moreover, appellate judicial decision making is so clearly a product of multiple factors, so subject to casespecific contingencies, that the search for a scientific or predictive theory of intercourt variation among ssCs, while feasible in principle, ${ }^{97}$ may in fact not be worth much further effort.

The failure of our analysis to disclose strong correlations between elements of judicial background and certain characteristics of ssc decisions also suggests that the variations among judges that we studied were not extreme. In twentieth-century United States, there may not be such great differences, on balance, between those who were previously small-town lawyers and those who were previously urban lawyers, between former prosecutors and former politicians, between the judicially experienced and the judicially inexperienced, between those educated in elite law schools and those who were not. Just as important, those categories, as well as labels like Republican and Democrat are so broad, each encompassing such a wide variety of individual

93. See, e.g., Philip E. Johnson, The Accidental Decision and How It Happens, 65 Calif. L. Rev. 231 (1977); John B. Oakley \& Robert S. Thompson, Law Clerks and the Judicial Process (Berkeley: University of California Press, 1980).

94. See, e.g., Arthur T. Vanderbilt II, Changing Law: A Biography of Arthur T. Vanderbilt (New Brunswick, N.J.: Rutgers University Press, 1976).

95. See, e.g., Robert A. Kagan, What If Abe Fortas Had Been More Discreet? in Nelson Polsby, ed., What If? Explorations in Social Science Fiction (Lexington, Mass.: Lewis Publishing, 1983).

96. See Gibson, supra note 1.

97. For sophisticated examples, at the trial-judge level, see Caldeira, supra note 91, and James L. Gibson, Environmental Constraints on the Behavior of Judges: A Representational Model of Judicial Decision Making, 14 Law \& Soc'y Rev. 343 (1980). For a valuable study examining the effect of lawyers' briefs on SSC decisions, see Thomas B. Marvell, Appellate Courts and Lawyers (Westport, Conn.: Greenwood Press, 1978). 
experiences and attitudes, that variations within the categories are almost as significant as variations between them.

Perhaps the most striking finding of this study is the great diversity of career paths to most ssCs. Despite tendencies of some courts to favor one kind of background over another, throughout the century most sscs have had judges drawn from a variety of prior careers, types of legal practice, law schools, and locations. Over all, therefore, while we must remind ourselves of the stark exclusion of blacks and women from sscs, the judges have not come predominantly from any particular legal or political background. The courts themselves, accordingly, have continually had to absorb new influences and reconstruct their internal cultures. Consequently, "scientific" explanations for judicial behavior are likely to be both complex and elusive. 


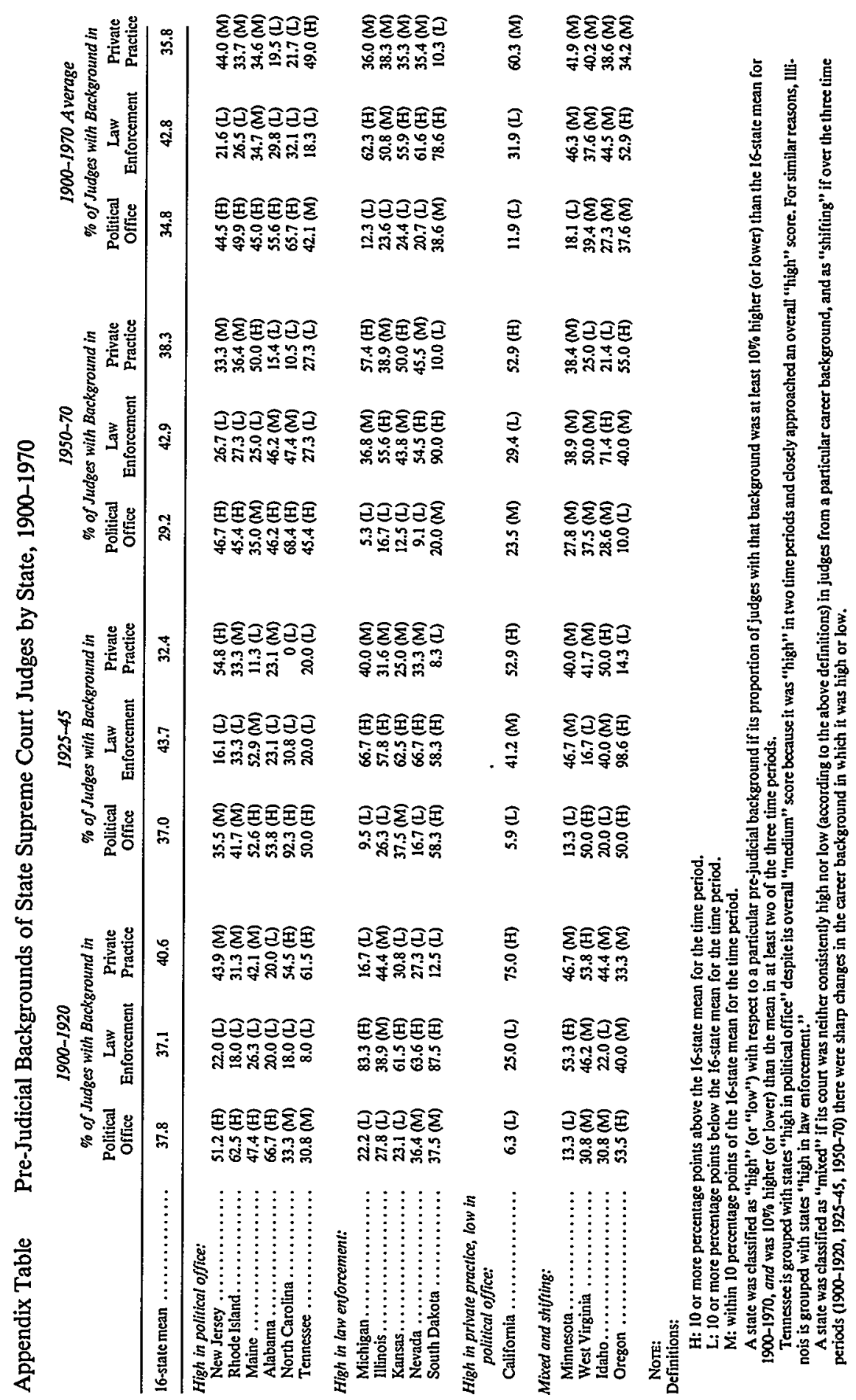

